$$
\frac{30}{8} \frac{9}{9}{ }^{0} \frac{a}{\frac{a}{9}}
$$

$$
5 \frac{5}{2} \frac{i}{\frac{5}{5}}
$$

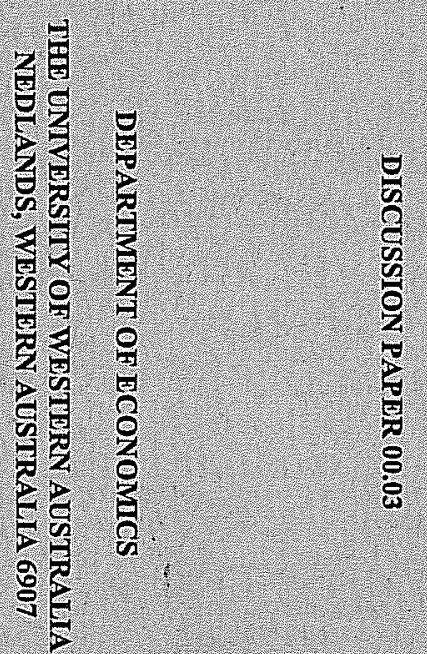



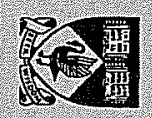


by

Anh T. Le

and

Paul W. Miller

Department of Economics The University of Western Australia

DISCUSSION PAPER 00.03

DEPARTMENT OF ECONOMICS

THE UNIVERSITY OF WESTERN AUSTRALIA NEDLANDS, WESTERN AUSTRALIA 6907

* Financial assistance under the Australian Bureau of Statistics' SEUP Research Fellow and from the Australian Research Conncil is gratefully acknowledged. The views in th those of the authors and should not be attributed to the funding agencies. We are grat Kenyon and two anonymous referees for helpful comments. 


\section{AUSTRALIA'S UNEMPLOYMENT PROBLEM}

A number of Australian studies have provided microeconomic and macroeconomicperspectives on the causes of, and solutions to, Australia's unemployment problem. This paper provides an evaluation of these studies. Several important findings can be noted. First, from the cross-sectional studies economists have gained a good understanding of the factors contributing to a high probability of unemployment. Effective use is curently being made of this information. Second, there is general consensus from the time-series studies regarding the estimates of the aggregate labour demand wage and output elasticities. In addition, it has been widely acknowledged that lower real wages and economic growth would help reduce the high rate of unemployment. Despite the infornation available we are making slow progress towards reducing the unemployment rate. This may be due to political reasons or because we are unsure of how to deliver the wage cuts and faster rates of economic growth presented as solutions to the unemployment problem. 


\section{AUSTRALIA'S UNEMPLOYMENT PROBLEM}

\section{INTRODUCTION}

In January and February 1993 and again in February 1994 the number unemployed in Australia exceeded one million. Since then the number unemployed has not fallen much below 700,000. In December 1999, for example, 667,200 persons were unemployed, giving an unemployment rate of 6.9 percent. Unemployment is one of Australia's major social and economic problems: it has obvious and well documented links to economic disadvantage, and has also been linked in some discussion to higher crime rates (Bodman and Maultby (1996)), especially among the young, and to ill health (see, for example, Graetz (1992), Morrell, Taylor and Kerr (1998)). The loss of GDP associated with an unemployment rate above the full-employment rate is conservatively estimated at the equivalent of one year's worth of GDP over the past two decades (Kenyon (1998)).

How can Australia's unemployment problem be addressed? The majority of Australian research, particularly that undertaken in more recent times, has adopted a microeconomic approach. In these studies, the incidence of unemployment in various groups has been studied, and potential causal factors identified. Factors such as age, educational attainment, language skills, birthplace and region of residence have been advanced as possible contributors to relative unemployment outcomes. Some research has extended the scope of the inquiry through examination of the relationship between unemployment outcomes and the person's labour market history. A strong scarring effect of unemployment has been reported in these studies.

It would be safe to say that the attempts at quantifying the links between the probability of unemployment and various personal, regional and job market characteristics have reached a consensus view of the factors that are important in this regard. In other words, we now have a reasonably good description of the unemployed. While such a statistical portrait is useful, and indeed should be an essential input into policy analysis, it is not clear that much progress has been made in applying the research results in analysis of the unemployment problem. There appear to be two main ways the empirical findings can be 
attainment and the incidence of unemployment, then additional education might be proposed as a way of increasing an individual's probability of job success.

Second, there is an opinion that the findings can be used in case management. In this application of the research findings, knowledge that early school leavers with poor English skills have relatively high rates of unemployment might lead to the conclusion that individuals having this combination of characteristics, or any other combination of characteristics known to be associated with relatively high rates of unemployment, should be case-managed

This theme is prevalent in the research of Miller and Volker (1987). They build upon work undertaken by the Australian Institute of Multicultural Affairs (1985) by using models of unemployment to identify individuals who were relatively more prone to prolonged periods of unemployment. A model of unemployment was estimated and the estimated coefficients used to compute for each individual an index that measured the risk of being unemployed. Using this approach, a group categorised as being at risk of, or prone to, unemployment could be isolated. Miller and Volker $(1987$, p.28) report that "Many of the groups distinguished under the risk index approach, therefore, are characterised by well-defined intervening factors". This implies that the risk index approach, and the associated study of unit-record data, have direct policy applications. A risk-index approach underlies the Job Seeker Classification Instrument developed by the Department of Employment, Education, Training and Youth Affairs (DEETYA) (1998) for case management purposes.

Improving the employment prospects of any one individual may, however, simply reorder the queue of the unemployed. Policy should also be directed at creating more jobs. It is in this context that the time-series research has a dominant role. This research has examined a range of factors that may impact on the overall level of unemployment in Australia. Included are real wages, rates of growth and institutional arrangements. The relationships reported are consistent with economic theory. They also seem to be important in terms of economic magnitudes. In other words, we have a reasonably good understanding of what causes unemployment. Accordingly, the high unemployment rate that Australia has experienced over the past two decades may, as described by the Secretary to the Treasury, Mr Ted Evans, be a matter of choice. ${ }^{1}$

In this study we provide a critical evaluation of applied research on unemployment in Australia. Section II covers definition issues and the changes in the unemployment rate in recent decades. Section III reviews some of the data linking personal characteristics of labour force participants to unemployment outcomes. It assembles the main crosssectional evidence and identifies the common themes of the Australian research and the controversies. It also provides evidence on the problem of the long-term unemployed. Section IV looks at the time-series evidence. This section covers the key relationships between unemployment and real wages and economic growth, as well as more populis solutions such as work sharing. It examines applications of the time-series evidence as providing solutions to the unemployment problem, and includes in this is a review of the role of labour market programs. Section $V$ provides a summary and conclusion.

\section{UNEMPLOYMENT IN AUSTRALIA: BACKGROUND}

\section{The Relevance of the Unemployment Statistics}

Unemployment statistics are used in a variety of situations, but mostly as an indicator of the under-utilisation of a nation's resources and of the economic and social hardship associated with the absence of employment. Users of these statistics are usually well acquainted with at least some of their deficiencies. "There have been several recent attempts to raise the level of awareness of these deficiencies, including the work by Chapman (1990) and a series of papers by Wooden, for example, Wooden (1993)(1996), and Ross, for example, Ross(1985)(1992).

These papers draw attention to the categories of under-utilisation of labour not captured by the conventional definition of unemployment. These include visible underemployment (i.e., an employed person who works fewer hours than desired), invisible underemployment (i.e., an employed person whose actual working time is not used to potential), and discouraged workers (i.e., those who no longer seek work due to their perception that suitable jobs are not available). Wooden (1996) quantifies these categories, with his estimates for September 1995 revealing that only 48 percent of the

'See Wood (1997) 
underutilised labour hours were in the "unemployment" category, 17 percent were in the "visible underemployment" category, 28 percent in the "invisible underemployment" category, and 10 percent were in "hidden unemployment". It is noted that visible unemployment appears to vary appreciably across individual characteristics (e.g., age, gender, marital status), while hidden unemployment does not vary greatly across these characteristics (see Wooden (1996)). Flatau, Petridis and Wood (1995) report that invisible unemployment is at significant levels among immigrants from non-English speaking countries.

Situations where the official unemployment category counts for only around one-half of the total under-utilisation of labour suggest that the official unemployment rate is not reflective of the true state of the labour market. It also means that forecasting change in the official unemployment count will be quite difficult. In many period, the employment effects of increases in economic activity can be absorbed by higher rates of utilisation of the employed, or by flows into the labour market of discouraged job seekers, rather than by reductions in the official unemployment category.

\section{Teenage Unemployment Statistics}

A further issue relates to data on teenage unemployment. Treasury (1999) argues for the use of alternative measures of teenage unemployment to accommodate teenage involvement in secondary and post-secondary education. They see this as necessary as the policy responses to job seeking among teenagers need to be particularly sensitive to their educational circumstances. They provide the following ways of viewing teenage unemployment data.
Table 1

Alternative Measures of Teenage Unemployment Teenage Total (15yrst)

\begin{tabular}{|c|c|c|c|}
\hline Series & $\begin{array}{r}\text { Teenage } \\
\text { rate (a) }\end{array}$ & $\begin{array}{r}\text { Total (15yrs+) } \\
\text { rate (a) } \\
\end{array}$ & Focus/policy issue \\
\hline $\begin{array}{l}\text { (1) Full-time } \\
\text { unemployment rate }\end{array}$ & 23.0 & 7.2 & $\begin{array}{l}\text { Focus on subset participating in or looking for full- } \\
\text { time work. Less meaningful for teenagers now } \\
\text { due to changes in educational participation. }\end{array}$ \\
\hline $\begin{array}{l}\text { (2) Full-time } \\
\text { unemployment to } \\
\text { population ratio }\end{array}$ & 4.9 & 3.3 & $\begin{array}{l}\text { Represents the percentage in the particular group } \\
\text { looking for full-time work. Less meaningful now } \\
\text { due to changes in educational participation. }\end{array}$ \\
\hline $\begin{array}{l}\text { (3) Total } \\
\text { unemployment rate }\end{array}$ & 16.6 & 6.9 & $\begin{array}{l}\text { The standard series which includes those looking } \\
\text { for either full-time or part-time work as a } \\
\text { proportion of the labour force. The appropriate } \\
\text { teenage series to compare with the 'headline' rate. }\end{array}$ \\
\hline $\begin{array}{l}\text { (4) Total } \\
\text { unemployment to } \\
\text { population ratio }\end{array}$ & 9.3 & 4.3 & $\begin{array}{l}\text { Represents the percentage looking for either full- } \\
\text { time or part-time work. A better measure of the } \\
\text { overall risk facing teenagers given the high rate of } \\
\text { non-participation in the labour force. }\end{array}$ \\
\hline $\begin{array}{l}\text { (5) Unemployment } \\
\text { rate for those not } \\
\text { attending full-time } \\
\text { education }\end{array}$ & 17.6 & n.a. & $\begin{array}{l}\text { For teenagers, focuses on the 'at risk' group and } \\
\text { represents the percentage not in full-time } \\
\text { education and in the labour force looking for full- } \\
\text { time or part-time work. }\end{array}$ \\
\hline $\begin{array}{l}\text { (6) Unemployment } \\
\text { to population ratio } \\
\text { for those not } \\
\text { attending full-time } \\
\text { education }\end{array}$ & 15.5 & n.a. & $\begin{array}{l}\text { Also focuses on the 'at risk' group and represents } \\
\text { the percentage not in full-time education looking } \\
\text { for full-time or part-time work. }\end{array}$ \\
\hline $\begin{array}{l}\text { Note: } \text { n.a. not app } \\
\text { (a) Based } \\
\text { Preliminar }\end{array}$ & 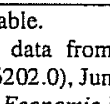 & & au of Statistics, The Labour Force, Aust \\
\hline
\end{tabular}

While most commentators recognise these types of limitations of the unemployment data, most studies are based on the headline unemployment rate.

\section{The Headline Unemployment Rate}

Figures 1 and 2 provide seasonally adjusted information on the dimensions of Australia's unemployment problem. Figure 1 plots the number unemployed between March 1978 and December 1999. These data relate to individuals aged 15 or more years. Separate data are presented for males, females and all persons. Figure 2 plots the unemployment rates for these groups. 


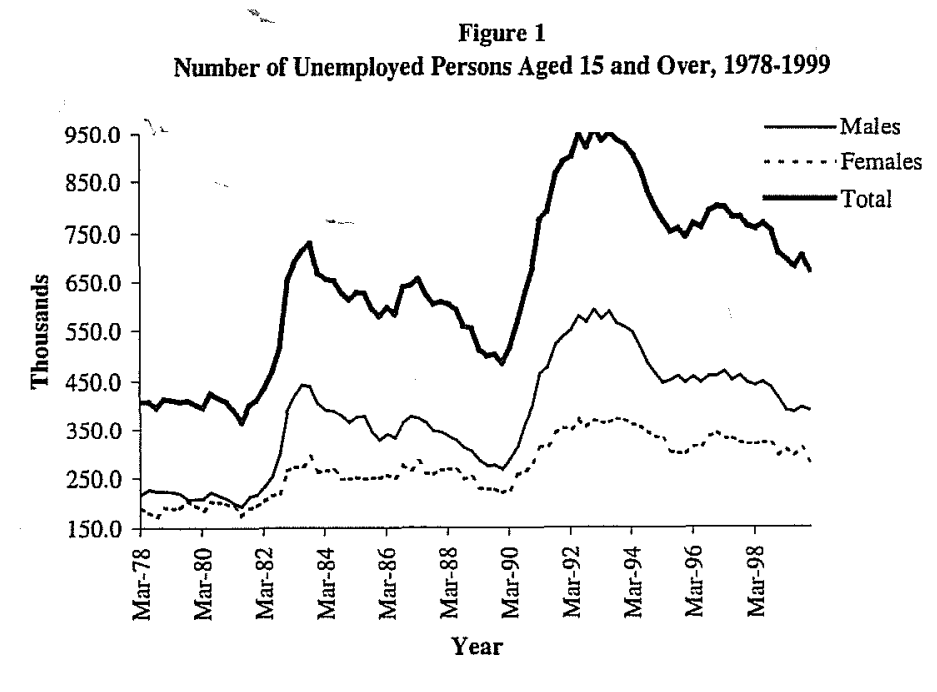

Figure 2

Unemployment Rate of Persons Aged 15 and Over, 1978-1999

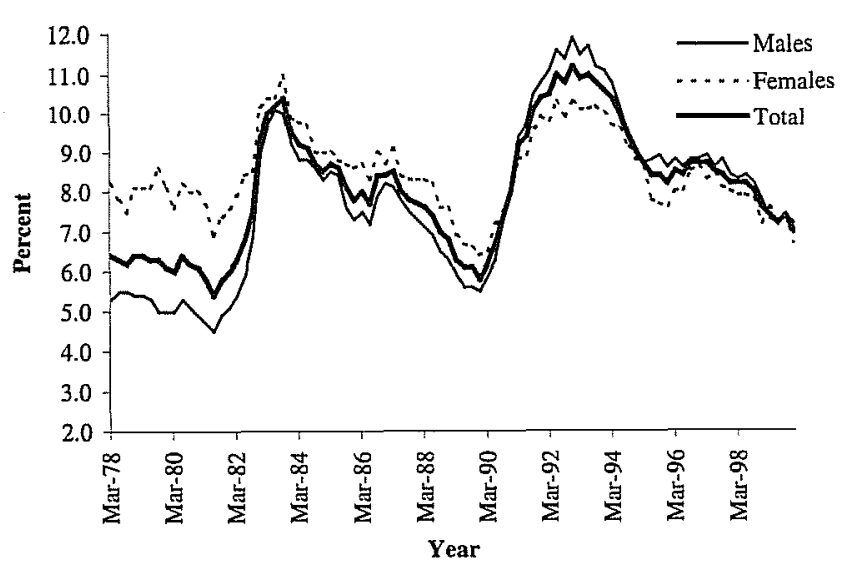

Source: ABS, unpublished data, Labour Force Survey.
These figures demonstrate the sharp deterioration in the labour market in 1983, the gradual improvement in the unemployment position between 1983 and 1990, the extended deterioration in the labour market between 1990 and 1993, and the improvements in the labour market since 1993. Of particular interest to many commentators is the unemployment numbers. Between 486,000 and 656,000 persons were unemployed in Australia in the late 1980s. But by the 1990 s the numbers unemployed were often 1.5 times these levels.

Unemployment clearly affects a large number of people, and this stresses the importance of understanding how the problem can be alleviated.

\section{CROSS-SECTIONAL RESEARCH}

The microeconomic research on unemployment in Australia has generally taken one of three broad approaches. First, unemployment differentials in the entire workforce are examined. Second, relative labour market outcomes for particular demographic groups (e.g., women, immigrants) are examined. Third, the long-term unemployed are studied. In this section the evidence on unemployment outcomes for the entire workforce and for a number of demographic groups is first reviewed. Then the research on the long-term unemployed is examined.

Three types of determinants of unemployment have been analysed in cross-sectional studies: those that affect unemployment outcomes through human capital effects; composite variables such as birthplace and gender that will capture the influences of a range of phenomena, including discrimination, pre-labour market choices and other unobserved factors that are correlated with the particular characteristic; and past labour market experiences that affect current labour market outcomes. Within this broad framework, individual studies differ in their approach, and these differences are usually associated with features or limitations of the data set being used.

\section{Human Capital Effects}

The types of human capital that may impact on unemployment outcomes include formal education, qualifications, English language skills and the accumulation of knowledge of the labour market (best practice with respect to job search processes, information networks) that occurs through labour market activity. Educational attainment is arguably 
the most important of these. Table 2 presents data on the unemployment rate across educational attainment categories for May 1999. ${ }^{2}$ These data show that there is a pronounced, inverse association between unemployment and educational attainment. The unemployment rate of those who did not complete the highest level of school available is 5.7 times that of individuals who possess a higher degree.

Table 2

Unemployment by Educational Attainment for Persons Aged 15-64, May 1999 Educational attainment Higher degree

Postgraduate diploma

Bachelor degree

Undergraduate diploma

Associate diploma

Skilled vocational qualification

Basic vocational qualification

Completed highest level of school

Did not complete highest level of school

Still at school

Total

Note: "Subject to sampling variability too high for most practical purposes.

Source: ABS (May 1999b) Transition from Education to Work, 6227.0, Table 11. Unemployment rate $(\%)$

Reflecting the strong pattern evident in Table 2, educational attainment has been a focus in most multivariate studies of unemployment outcomes in the Australian labour market. ${ }^{3}$ These studies show that even when other potential influences on unemployment outcomes are held constant, knowledge of a person's educational attainment is a key to knowing the probability that they will be unemployed. Brooks and Volker (1985), Inglis and Stromback (1986), Miller (1986)(1998), Beggs and Chapman (1988), Jones (1992), Harris (1996), Miller and Neo (1997) and Le and Miller (1999), for example, all report a strong, inverse relationship between the incidence of unemployment and educational attainment. ${ }^{4}$ An additional year of education is reported to be associated with up to a 2 percentage point reduction in the predicted incidence of unemployment in some studies (see, for example, Miller and Neo (1997)). Studies that include information on education

${ }^{2}$ Data are presented, where possible, for November 1999. Where data are not available for November 1999 , the latest data available up to this point will be used.

A detailed outline of the main cross-sectional studies of unemployment is presented in Appendix A.

The education data generally comprise years of schooling and post-secondary qualifications. Some studies construct a continuous measure of the "years of full-time equivalent schooling" from these data (e.g., Beggs and Chapman (1988)) while others use a set of categorical variables to represent the highest level of educational attainment (e.g., Inglis and Stromback (1986)) categories of the type included in Table 2 show that completing high school is crucial to employment success. For example, Table 3 lists the partial effects of educational attainment on the probability of being unemployed from Le and Miller (1999). These effects are.derived from multivariate analyses and so abstract from the compounding influences of other determinants of unemployment. The effects listed are relative to the benchmark group given in the note to the Table. For example, holding all other characteristics constant, a university graduate has an unemployment rate 9.76 percentage points below that of individuals who left school at 15 years of age or younger, or who never attended school, and who do not possess a post-secondary qualification.

Table 3

The Partial Effects of Educational Attainment on the Probability of being Unemployed

\begin{tabular}{lc}
\hline Educational attainment & Partial effect on unemployment \\
\hline Bachelor degree or higher & -9.76 \\
Undergraduate or associate diploma & -8.54 \\
Skilled vocational qualification & -6.56 \\
Basic vocational qualification & -5.77 \\
Attended highest level of secondary school & -5.87 \\
Left school aged 16 years and over & -1.76 \\
\hline Note: The benchmark category of education comprises individuals who left school at 15 years of age or \\
$\quad$ younger, or never attended school, and do not possess a post-secondary qualification.
\end{tabular}

According to the human capital model, these powerful unemployment effects are due to the value added by education. In other words, education enhances (adds to).the set of factors that are linked to the individual's productivity in the labour market. An alternative explanation is that of screening. According to this explanation, education does not directly affect an individual's productivity, but rather the education system simply provides a mechanism through which an individual's innate ability can be determined. The outcome again is that additional years of education are associated with higher productivity and hence lower rates of unemployment.

Both human capital and screening therefore rely upon there being a link between the level of education and the individual's productivity. However, the policy conclusions differ appreciably. Under the human capital interpretation, encouraging the less-well educated to undertake additional schooling would be expected to lead to lower rates of unemployment among the targeted group. From the screening perspective, however, promoting education among the less well educated will not directly affect the level of 
their productivity, and there will consequently be little impact on rates of unemployment among the targeted group. Attempts to attach relative weights to screening and human capital interpretations of labour market phenomena have not met with much success (Weiss (1995)).

Age (or labour market experience) is another factor that has been shown to be an important determinant of unemployment outcomes. Table 4 shows the variation in the unemployment rate across 7 age groups. It can be seen that the incidence of unemployment is relatively high among youth. Among the older age groups, unemployment rates tend to be relatively high, a phenomenon that is often associated with discrimination on the basis of age, and obsolescence and depreciation of human capital. $^{5}$

Table 4

Unemployment by Age, November 1999

\begin{tabular}{lc}
\hline Age group (years) & Unemployment rate (\%) \\
\hline $15-19$ & 17.4 \\
$20-24$ & 8.8 \\
$25-34$ & 5.8 \\
$35-44$ & 5.1 \\
$45-54$ & 4.1 \\
$55-59$ & 5.6 \\
$60-64$ & 4.1 \\
Total & 6.4 \\
\hline Source: ABS (November 1999a), Labour Force, Australia, 6203.0, Table 24.
\end{tabular}

Source: ABS (November 1999a), Labour Force, Australia, 6203.0, Table 24

Some studies use an age variable to capture these effects (e.g., Wooden (1991), Le and Miller (1999)) while others use a measure of labour force experience (e.g., Beggs and Chapman (1988)). Various functional forms have been used, including continuous variables (e.g., Miller and Neo (1997), Beggs and Chapman (1988), Le and Miller (1999)), linear splines (e.g., Inglis and Stromback (1986)) and a set of dummy variables (e.g., Ross (1993)). These studies report that, among the early age groups, unemployment rates decline with age or labour market experience. The unemployment rate reductions are most pronounced in the 15-24 age bracket. In the older (i.e., post-45 years) age groups, however, there is a tendency for unemployment rates to increase with

\footnotetext{
${ }^{5}$ The relatively low rate of unemployment among 60-64 year olds may be due to labour force withdrawal in this age category.
}

additional years of experience. However, most studies report that the age effects on unemployment rates in the post-24 years group are modest.

Among the other human capital variables included in many models are variables for English language skills. Inglis and Stromback (1986), for example, distinguish individuals who speak a language other than English at home and self-report their English skills as "Good", those who speak a language other than English at home and self-report their English skills as "Poor" and monolingual English speakers. They find that the unemployment rates of monolingual English speakers and individuals who speak a language other than English at home and speak English "Good" do not differ from each other. However, the unemployment rates of individuals who have only "Poor" English skills are significantly greater than the unemployment rates of the other groups. Using more recent data, Miller and Neo (1997) and Le and Miller (1999) report that both groups who speak a language other than English at home have higher unemployment rates than monolingual English speakers, though the group with the lowest level of English language skills experiences the highest rate of unemployment. Table 5 lists the partial effects of English proficiency on the probability of being unemployed from a range of studies. It can be seen that the partial effects of poor English skills on the probability of being unemployed are much larger than those for good English skills. For example, consider the final row of data in the table that relates to fernale in the study by Miller and Neo (1997). These figures show that individuals who speak a language other than English at home and who self report their English skills as "Good" have an unemployment rate 2.07 percentage points higher than the unemployment rate of monolingual English speakers when all other characteristics are held constant. In comparison, those who self-report their English skills as 'Poor" have a 6.67 percentage points unemployment rate disadvantage compared to monolingual English speakers, ceteris paribus. 
Table 5

The Partial Effects of English Proficiency on the Probability of being Unemployed Study/Sample Partial effect on unemployment Good English

Poor English

Inglis and Stromback (1986)

Males

$-0.13$

4.55
0.47

Females -0.13
0.70

4.55
0.47

Le and Miller (1999)

Total

Miller (1998)
Males

Males

Females
Miller and Neo (1997)

0.70

10.40

1.15

274

Males

6.42

2.74

2.14
2.07

4.40

Females 6.67

Note: The benchmark group comprises individuals who speak English only.

The language skill variables have direct links to policy formulation. Groups with poor English skills experience relatively high rates of unemployment. The provision of English-as-a-second-language courses is therefore a possible policy response.

Several studies have analysed the impact of disabilities on the unemployment outcome (e.g., Junankar and Wood (1992), Harris (1996), Le and Miller (1999)). Harris (1996), for example, includes in his analysis a variable for whether the respondent suffered from any disability or health problem that limited either the amount or type of work they could do. This was a highly significant determinant of unemployment. Le and Miller (1999) likewise report that labour force participants with disabilities are significantly more likely to be unemployed than other labour force participants. Harris (1996, p.127) indicates that the unemployment disadvantage of individuals with disabilities should be addressed.

There are a number of other individual characteristics that are generally included in models of unemployment, including marital status, location and mobility status. These are likely to reflect a wider range of influences. Marital status variables, for example, are thought to capture both demand-side and supply-side influences. From the supply-side perspective, the greater family responsibilities of married males are expected to increase their incentive to work, while from the demand-side perspective, employers may be more likely to employ married males because they are held to have greater work commitment, be more reliable and potentially more productive. Among females, married women's lower degree of labour force attachment has often been raised as an issue. The Table 6 data show that the unemployment rate of both unmarried males and females is more than double that of their married counterparts.

\section{Table 6}

Unemployment by Marital Status for Persons Aged 15 and Over, November 1999

\begin{tabular}{lccc}
\hline Marital status & $\begin{array}{c}\text { Male unemployment } \\
\text { rate (\%) }\end{array}$ & $\begin{array}{c}\text { Female unemployment } \\
\text { rate (\%) }\end{array}$ & $\begin{array}{c}\text { Total unemployment } \\
\text { rate (\%) }\end{array}$ \\
\hline Married & 3.6 & 3.8 & 3.6 \\
Not married & 11.5 & 9.8 & 10.7 \\
Total & 6.6 & 6.2 & 6.4 \\
\hline
\end{tabular}

Source: ABS (November 1999a), Labour Force, Australia, 6203.0, Table 4.

Most studies of unemployment recognise the importance of marital status by including a 'married' variable in the estimating equation. In some studies (e.g., Inglis and Stromback (1986), Harris (1996)) more elaborate specifications which distinguish the married according to the labour force status of the spouse are considered. It has been reported that marital status has an important impact on the probability of being unemployed. Among males, the lowest rates of unemployment are experienced by the married. Among females, the married also have the lowest rate of unemployment, but usually only if the spouse is employed. The estimated marital effects in the unemployment regression models are generally of the order of magnitude as suggested in Table 6. The reasons for these marital status effects are, however, not clear. Disaggregation of the marital status effect by the employment status of the spouse suggests that the design of the social security system may have a role to play (see Miller and Neo (1997)). Dependency based payments for the spouse of a welfare recipient will discourage employment and encourage unemployment or non-participation. A requirement for married couples without children to qualify for income support in their own right (rather than as a dependent spouse) will tend to result in lower levels of non-participation among the spouses of the unemployed. These issues are reviewed in Whitlock (1994).

The final "personal characteristic" variable that will be considered here is location. Table 7 presents the unemployment rate of individuals aged 15 and over across States or Territories in November 1999. These data show that the unemployment rates in New South Wales, Western Australia, the Northern Territory and the Australian Capital Territory are (in late 1999) relatively low while those in Queensland, South Australia and Tasmania are relatively high. 
Table 7

Unemployment by State or Territory for Persons Aged 15 and Over, November 1999

\begin{tabular}{lc}
\hline State or Territory & Unemployment rate (\%) \\
\hline New South Wales & 5.3 \\
Victoria & 6.6 \\
Queensland & 7.4 \\
South Australia & 7.7 \\
Western Australia & 6.4 \\
Tasmania & 9.6 \\
Northern Territory & 3.4 \\
Australian Capital Territory & 5.6 \\
Total & 6.4 \\
\hline Source: ABS (November 1999a), Labour Force, Australia, 6203.0, Table 5.
\end{tabular}

Variables for location have been included in studies such as Inglis and Stromback (1986), Bradbury, Garde and Vipond (1986), Ross (1993), Harris (1996) and Le and Miller (1999). Specification differences limit the extent to which comparisons can be made across studies. For example, some studies include 'metropolitan' and 'non-metropolitan' variables. An alternative approach is to include variables for 'urban', 'rural', 'major urban' or 'other urban'. A more general measure of location used is to include regions such as 'far south coast' or 'north west'. Generally, the rates of unemployment are higher in rural areas than elsewhere (e.g., Bradbury, Garde and Vipond (1986)), though the differences in this regard are not always statistically significant when examined in a multivariate framework (e.g., Inglis and Stromback (1986), Le and Miller (1999)).

\section{Location: Some Twists to the Tale}

It is apparent from the discussion above that location has some bearing on unemployment outcomes. Many of the regional differences in unemployment rates seem to have persisted for decades. Western Australia, for example, has a reputation as a low unemployment state, Tasmania a reputation as a high unemployment state. Even larger unemployment rate differentials exist among local labour markets within each state.

Gregory and Hunter (1995)(1996) demonstrate that employment performance has been different across neighbourhoods within each state, with employment prospects being much stronger in good neighbourhoods than in poor neighbourhoods. They show (Gregory and Hunter (1995)) that the rising tide of joblessness in areas of low socioeconomic status covers all age groups, but is more heavily concentrated in older age groups. These patterns have contributed to the polarization in Australian society on a neighbourhood level as well as at the level of the individual. Gregory and Hunter (1995) link this uneven impact of the macroeconomic downtum to the decline in the manufacturing sector following reductions in the degree of protection afforded this industry sector. Manufacturing employment is concentrated in poor neighbourhoods.

Unemployment rates in the various regions should tend to converge over time owing to worker mobility. The links between unemployment rates and worker mobility have been studied from two perspectives. First, worker mobility variables have been included in estimating equations explaining unemployment rates. Second, unemployment rate variables have been included in models used to account for worker mobility.

Examples of studies where internal migration variables are included in models of unemployment include Inglis and Stromback (1986) and Bradbury, Garde and Vipond (1986). Both studies show that the chances of being unemployed are much higher if the individual had moved in the past five years, and particularly so if the move had taken place within the previous year. This association could be due to the unemployed moving in search of work or due to the geographical mobility resulting in unemployment. The latter association might arise where a person who has moved lacks the detailed knowledge of the labour market in the new region of residence that is essential to a smooth transition into employment. Both Bradbury, Garde and Vipond (1986) and Miller (1998) argue that the patterns observed when the unemployment-mobility association is analysed across various subgroups suggest that the direction of causation is most likely from moving place of residence to unemployment.

Several studies have also examined the consequences of local labour market conditions for internal migration decisions. Debelle and Vickery (1999), for example, report that relative labour market conditions among states and inter-state migration decisions are linked, in a predictable way. As one might expect, the adjustment mechanism is slowmost of the worker mobility in response to a labour market shock takes place within four years, but it takes seven years to work through fully. Debelle and Vickery (1999) also report evidence of permanent differences between state unemployment rates, which may reflect compensating lifestyle differentials. Kilpatrick and Felmingham (1996) also report a positive association between unemployment rates and worker mobility, though 
this varies appreciably across years, states and gender. In their study mobility is modelled as a function of the state of the labour market: as Kilpatrick and Felmingham (1996) note, there is a need to model unemployment rates in the different regions explicitly if the interest is in explaining inter-regional unemployment rate differentials.

\section{Birthplace, Gender and Race}

Studies that focus on relative employment outcomes for particular demographic groups in Australia have typically focused on one of three groups: women, immigrants and Indigenous Australians. The data in Table 8 show the unemployment rates of Indigenous and non-Indigenous Australians in 1996. It can be seen that Indigenous Australians experienced a much higher rate of unemployment than non-Indigenous Australians. Given a large difference in the unemployment rate between the two groups, it seems important that race be controlled for in studies of unemployment in the Australian labour market.

Table 8

Unemployment of Indigenous and non-Indigenous Australians Aged 15 and Over, 1996

\begin{tabular}{|c|c|}
\hline Race & Unemployment rate (\%) \\
\hline Indigenous Australians & 22.7 \\
\hline Non-Indigenous Australians & 9.0 \\
\hline Total & 9.2 \\
\hline
\end{tabular}

Source: ABS (1998), 1996 Census of Population and Housing: Aboriginal and Torres Strait Islander People, 2034.0, Table 4.1.

Miller (1990), Jones (1990) and a number of other studies have analysed the unemployment position of Indigenous Australians relative to that of non-Indigenous Australians. These studies generally show that Indigenous Australians experience a serious employment disadvantage in the labour market. Harris (1996) and Le and Miller (1999) base their analyses on the inclusion of a variable for racial background in a model of unemployment. In other studies separate analyses are conducted for Indigenous Australians and non-Indigenous Australians (e.g., Miller (1990)). Both Miller (1990) and Jones (1990) show that even when other characteristics that may affect unemployment outcomes are held constant, in the mid 1980s Indigenous Australians had unemployment rates that were more than 20 percentage points higher than those of non-Indigenous Australians. More detailed analysis of the unemployment position of Indigenous Australians has been provided by Ross (see, for example, Ross (1990)(1993)), and the
Center for Aboriginal Economic Policy Research (see, for example, Taylor (1993)). The employment disadvantage of Indigenous Australians is arguably the greatest there is in the Australian labour market. Policies advanced to address this situation include improving access to and encouraging participation in education, improving access to employment opportunities in the private sector and the development of labour market programs structured to the economic, social and cultural needs of Indigenous people, along the line of the Community Development Employment Projects (see, for example, Ross (1990)). ${ }^{6}$

Labour market performances also differ between the Australian born and those who were born overseas; as well as between those born abroad in the main English-speaking countries and those who were bom in non-English speaking countries. Table 9 presents data on the variations in the unemployment rate across birthplace groups. It is observed that the overseas bom have a higher rate of unemployment than individuals who were born in Australia. However, the difference in this regard is very small.

Table 9

Unemployment by Birthplace for Persons Aged 15 and Over, November 1999

\begin{tabular}{lc}
\hline Birthplace & Unemployment rate (\%) \\
\hline Born in Australia & 6.4 \\
Bom outside Australia & 6.6 \\
Bom outside Australia in main English-speaking countries & 5.2 \\
Born outside Australia in other countries & 7.6 \\
Total & 6.4 \\
\hline
\end{tabular}

Source: ABS (Noventer 1999), Labour Force, Australia, 62030. Table 14

Among the overseas born, those who were born in non English-speaking countries experienced a high unemployment rate ( 8 percent) compared to those who were born in main English-speaking countries ( 5 percent). Therefore, it appears that immigrants from non-English speaking countries are the most disadvantaged birthplace group in the labour market.

Approaches similar to those used in the study of the unemployment rate disadvantage of Indigenous Australians have been used in the study of the unemployment situation of the overseas born. Hence, dummy variables for a number of birthplace groups have been included in some analyses (e.g., Inglis and Stromback (1986), Le and Miller (1999))

\footnotetext{
${ }^{6}$ See Morony (1990) for discussion on the Community Development Employment Project scheme.
} 
while models of unemployment have been estimated for separate samples of the foreign bom and Australian born in other studies (e.g., Miller and Neo (1997)). The studies show that most groups of migrants from non-English speaking countries in Australia experience a substantial unemployment rate disadvantage in the labour market. The studies also report that migrants' unemployment rates improve rapidly with duration of residence in Australia, and are adversely affected by migrants' limited English skills. Migrants also appear to be at an unemployment rate disadvantage due to the less-thanperfect international transferability of human capital (see in particular Beggs and Chapman (1988)). McDonald and Worswick (1999) show that it is important to take account of age at arrival when studying unemployment effects among immigrants: when this is done there is little evidence of cohort effects. This evidence on cohort effects is important, as it has been argued that a change in immigrant employment outcomes with duration of residence could be due to changes over time in unmeasured dimensions of immigrant quality rather than an adjustment effect (see Borjas (1985)). ${ }^{7} \mathrm{McD}$ Donald and Worswick (1999) also show that the duration of residence or adjustment effects in their study vary by age at arrival, being more pronounced for immigrants who arrive as adults.

The data on the link between unemployment and gender show that the unemployment rate for males, as at November 1999, was higher (7 percent) than that of female labour market participants (6 percent), though this difference is quite minor. This represents an unadjusted or gross gender differential in unemployment rates that is quite different to that which prevailed a decade ago (see Figure 2).

There have been some studies that examine differences on the basis of sex in rates of unemployment (e.g., Australian Institute of Multicultural Affairs (1985), Bradbury, Garde and Vipond (1986)), though these are relatively few in number. The reason for this is concern over whether the unemployment rate provides a relevant measure of the labour market prospects for women, given their lower degree of attachment to the labour market and the greater sensitivity of their unemployment rate to the limitations outlined in Section II. It is generally argued that there are few policy responses that could be

\footnotetext{
${ }^{7}$ The evidence on cohort effects in the US is mixed. See, for example, Borjas (1985) and Duleep and Regets
(1997).
}

based on differences in the headline unemployment rates between males and females (see, for example, the Australian Institute of Multicultural Affairs (1985, p.60)).

\section{Employment History}

Labour market performance in the current period can also be influenced by a person's previous labour market activities. That is, individuals normally remain in the same labour market activity over time unless there are major changes that would cause them to revise their work behaviour. This continuity is taken into account in inertia and state dependence models of labour market behaviour. In these models information on previous labour market activities is included in the models used to account for current labour market outcomes. This modification of the model has been shown to enhance considerably the predictability of labour market outcomes.

Nakamura and Nakamura (1985) examine the links between current and past labour market performance in the context of an inertia model. In inertia models the lagged information on labour market activity is usually interpreted as a proxy for unobserved variables (e.g., ability, motivation).

In state dependence models, being unemployed helps shape the character and behaviour of the individual. In situations of negative state dependence, the longer the person has been unemployed, the more difficult it will be to find work-because of the attitudes developed, the decay of work skills and the information conveyed to prospective employers by a lengthy spell of unemployment. This phenomenon is often labelled the "scar" effect of a spell of unemployment.

Relatively few studies in Australia have, however, examined the influence of the individual's employment history on current labour market activity. One attempt in this regard was by the Australian Institute of Multicultural Affairs (1985). They conclude (p.61) that "...young people who suffer long initial periods of unemployment (and thus have limited work experience) tend to have more difficulty in obtaining employment when older...". Similarly, Miller and Volker (1987) and Junankar and Wood (1992) both find that previous periods of unemployment reduce subsequent chances of being employed in the youth labour market. 
A more recent study by Le and Miller (1999) also reports that the time individuals have previously spent looking for work while not working in the previous year and the total time they have spent looking for work since they first left full-time education both have a positive impact on the probability of being unemployed. For example, individuals who spent 50 days looking for work in the previous year had a predicted unemployment rate of 15 percent. In comparison, those who spent four-fifths of the previous year (300 days) job seeking had a predicted unemployment rate of 89 percent.

While the specification of the estimating equation of unemployment is the same, the interpretation of the estimated coefficient on the lagged labour market indicator variable differs for the inertia and state dependence models. Determining which interpretation is the more appropriate is important from the case management perspective. Under the inertia model, a person's relatively high propensity to be unemployed is due to unobservable factors (e.g., poor work habits, lack of motivation). Knowing that the person has a high probability of being unemployed in this situation does not greatly assist with case management, other than perhaps providing a cheap screen. Under the state dependence interpretation, breaking the individual's cycle of unemployment is a useful intervention. In this regard, where panel data models have been estimated that control for unobserved heterogeneity, strong state dependence effects have been reported. ${ }^{8}$

\section{The Long-Term Unemployed}

Among the unemployed, there is a particular policy focus on the long-term unemployed. At November 1999, around one-third of the unemployed had been in this state for 12 months or more. To the extent that there is state dependence, there are adverse consequences from a large pool of the long-term unemployed. Changes in the natural rate of unemployment have been linked to changes in the duration composition of the unemployed, as the greater the proportion of all unemployment that is of long duration, the less efficient is labour market's job matching function (see Chapman (1997b) for a discussion). This is generally described as a form of structural unemployment, in that the long-term unemployed's actual or perceived skills are inadequate for the available vacancies. This structural mismatch has been afforded considerable emphasis in recent

\footnotetext{
${ }^{8}$ See, for example, Knights (1999).
}

discussion (Chapman (1997b)). Growth in the pool of long-term unemployment also has obvious income distribution consequences.

The long-term unemployed have been the focus of a number of studies. These have adopted several approaches. First, the long-term unemployed have been distinguished from other unemployed, and binary choice models estimated to predict the probability of being long-term unemployed. The formal statistical modelling undertaken as background to the Job Seeker Classification Instrument (see DEETYA (1998)) is representative of this approach. In this work, the aim was to forecast whether a jobseeker would be unemployed for 12 months or more. In Miller and Volker (1987), a similar analysis is undertaken, though the focus is on forecasting unemployment spells exceeding six months among labour force participants. In general the direction of impact of the factors used to explain long-term unemployment is the same as that reported in models of the incidence of unemployment.

The second approach has been to use statistical failure models. These models make greater use of the data than the binary choice models. A number of studies have used this approach, including Brooks and Volker (1986) using aggregate-level gross flows data, Chapman and Smith (1992) using individual-level data for youth, and Stromback, Dockery and Ying (1998) using individual level data covering all age groups. Brooks and Volker (1986) report evidence of significant negative duration dependence, as do Stromback et al. (1998). Chapman and Smith (1992) however, report positive duration dependence (although their estimates cannot reject a null of no duration dependence). They argue that the negative duration dependence in the study by Brooks and Volker (1986) may arise due to the limited control for heterogeneity. ${ }^{9}$ Stromback et al. (1998), however, include a wide range of regressors in their model and still find negative duration dependence. This suggests that the specific nature of state dependence is sensitive to the sample and adjustments made to the data. ${ }^{10}$

${ }^{9}$ Brooks and Volker (1986) disaggregate their data by age and gender and conduct estimations without further ${ }_{10}^{\text {co-variates within each sub-group. }}$

${ }^{10}$ Chapman and Smith (1992), for example, truncate all unemployment spells at 52 weeks. This is to (p.272) duration data". 
The factors associated with a more rapid exit from unemployment, and hence with less chance of becoming long-term unemployed, vary across the studies. Educational attainment, gender (with males being more likely to be long-term unemployed) and location (residence of rural areas appear particularly disadvantaged in this regard) were significant influences in Chapman and Smith's (1992) study, while age, educational attainment, labour force status of spouse, the years spent working and labour market assistance were significant factors in Stromback et al. (1998). Comparison of the estimated hazard functions and average completed durations of unemployment in Brooks and Volker (1986) show that these vary by gender and by age groups.

The studies by Stromback et al. (1998) and Brooks and Volker (1986) report interesting findings concerning the impact of various interventions in the labour market. Stromback et al.'s (1998) results show that registration with the Commonwealth Employment Service significantly reduced the duration of job seeking whereas participation in a labour market program and case management were both associated with longer duration of job seeking. However, the authors argue that these results may reflect unobserved heterogeneity, or be a reflection of the labour market program replacing a shorter period of job search rather than reflect state dependence per se.

Brooks and Volker (1986) use their estimates to examine a range of issues associated with government intervention in the labour market. These include the optimal timing of labour market assistance and the duration of the assistance. Applications of this type demonstrate the relevance of labour market research to policy making.

\section{Using the Results}

The statistical analyses of unemployment have been used in various ways in the literature. The study by Inglis and Stromback (1986), for example, uses the estimates to predict the frequency of unemployment among migrants and to assign weights to various factors that contribute to migrant unemployment. Miller and Neo (1997) use the estimates to partition the unemployment rate differential between migrants and the Australian borm into components that are due to differences in the marketable characteristics of the two birthplace groups and due to differences in the way these characteristics are linked to unemployment outcomes in the Australian labour market (a component often labelled discrimination in the literature). Most studies, however, simply quantify the relationship between various characteristics and the unemployment outcome and use these empirical relationships in commentary on the causes of unemployment and possible policy solutions (e.g., Harris (1996), Ross (1993)).

A more ambitious approach is undertaken by the Australian Institute of Multicultural Affairs (1985). In their model a measure of the individual's unemployment experience, given by the number of months unemployed per year of labour market activity, was related to the age, sex, educational attainment, labour market experience, type of work, birthplace and, among the foreign born, length of residence in Australia of a sample of labour market participants. The results from this analysis were then used to predict a value for the measure of unemployment experience for each respondent. On this basis four risk groups were identified: no, low, medium and high risk of unemployment. It was suggested that a points system could be constructed from the regression analysis (see, in particular, Australian Institute of Multicultural Affairs (1985), p.211)), with "risk" then being assessed through comparison of the points score and a threshold.

Miller and Volker (1987) also pursue a risk-index approach. They also use their model of unemployment to create an index of risk for each person. They then divide the population into groups "at risk" and "not at risk" of unemployment on the basis of a threshold that will generate a fraction of the sample "at risk" that is the same as the sample unemployment rate. Early school leavers, individuals with a history of joblessness and persons with an unemployed spouse were disproportionately represented in the "at risk" group and hence suggested as groups that could be targeted in labour market programs. A similar exercise is undertaken by Le and Miller (1999). They were also able to follow through time those identified at risk of being unemployed, and hence provide an assessment of the methodology. They found that those in the "at risk of unemployment" category spent considerable time looking for work in the following year, and are more likely to be absent from the labour market.

This way of using the results from cross-sectional models of unemployment has direct policy implications. The Department of Employment, Education, Training and Youth Affairs (DEETYA) (1998), for example, has constructed the Job Seeker Classification Instrument (JSCI) to identify the job seekers who are most disadvantaged in the labour market. This instrument identifies the difficulties job seekers are likely to have in finding 
jobs because of their personal circumstances and labour market skills. Information is collected for each job seeker on factors such as age, educational attainment, duration of unemployment, work experience, Aboriginal and Torres Strait Islander status, geographical location, disability/medical condition, and language and literacy. These data are used to compute a JSCI score for each job seeker. Based on their scores, the job seekers are then ranked according to their likely employment placement difficulty. This approach enables the job seekers who are most likely to experience long-term unemployment to be targeted for the special assistance which may enhance their employment prospects.

Australia has a rich tradition of assisting those in need. This assistance may alter the incentives of labour market participants. Initiatives that fall within the ambit of labour market programs are reviewed in Section IV. An examination of the impact of the social welfare system is provided here.

\section{The Social Welfare System}

Australia is generally regarded as a country with a generous social welfare system. ${ }^{11}$ A crucial period in this regard was the early 1970 s, where replacement rates ${ }^{12}$ increased sharply. As a proportion of adult minimum wages, these reached over 50 percent for most groups, and in excess of 100 percent for some groups when part-time employment is taken into account. When allowance is made for other social security benefits (e.g., rental assistance, medical and hospital treatment ${ }^{13}$ ), the welfare system is shown to be even more generous.

There have been a number of evaluations of the disincentive effects associated with a social welfare system of such generous proportions. These have been both descriptive and statistical. Among the largely descriptive analyses, Miller and Volker (1985) compare unemployment flow and duration data in Australia and Canada. They conclude (p.231) that "...variation in the unemployment insurance program parameters of qualifying work-periods and benefit period entitlement have minor impacts upon the

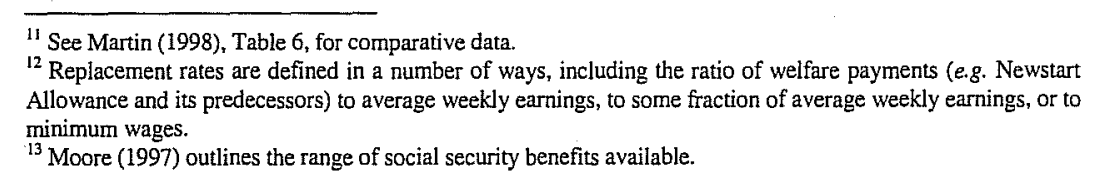

incidence and duration of unemployment". ${ }^{4}$ In terms of the monetary incentives, Gregory and Patterson (1980) report that the welfare take-up rate is greatly affected by increases in the level of payments. Trivedi and Kapuscinski's (1985) statistical analyses show that while the length of time individuals spent in unemployment was affected by the changes in the generosity of the welfare system, inflows into unemployment were not greatly affected. Whitlock's (1994) more recent evaluation also finds that more generous welfare payments to the unemployed affect the duration of unemployment but not necessarily the incidence of unemployment. Similarly, Bradbury (1993) reports that the behavioural responses to variations in replacements rates are quite weak, while Chapman and Smith (1992) find that the value of social welfare payments did not affect the duration of unemployment in the youth labour market. Finally, Harris (1996) found that the amount of unemployment benefit did not affect unemployment outcomes in the youth labour market. ${ }^{15}$

The gap between the strong predictions from theoretical models of income-leisure tradeoffs and the less certain evidence from the empirical studies may reflect the difficulty of isolating any pure "welfare" effects from other microeconomic (e.g. effects associated with family size and structure) and macroeconomic (e.g. structural changes) effects. However, it is clear that there is now a renewed interest in examining the entire range of benefits available (see, for example, Moore (1997)), and integrating these with the tax system (see, for example, Dawkins and Freebaim (1997)). Dawkins and Freebaim's (1997) earned income tax credit proposal is reviewed in Section IV.

\section{An Overview}

It seems fair to conclude that a degree of consensus has been reached regarding the primary determinants of the probability of being unemployed. Reflecting this reasonably secure state of the applied research, the estimates are being used in quite fundamental ways in the policy arena (see DEETYA (1998)). But while those most likely to have difficulties finding work can be identified with a high degree of success, and targeted for special assistance, the basic question remains of whether there are enough jobs available ${ }^{14}$ Layard, Nickell and Jackman (1991), however, report that the US evidence shows that the duration of benefit
availability is important.
${ }^{15}$ Moore's (1997) secondary analysis of a range of evidence, however, leads him to conclude that 'There seems
little doubt that such generosity (of the whole range of relevant cash and non-cash benefits in Australia) accounts for a significant proportion of Australia's existing rate of unemployment". 
for a large segment of the pool of unemployed to have a reasonable chance of gaining work. If sufficient jobs are not available, how can extra jobs be created? The answer to this question rests with time-series studies.

\section{TIME SERIES STUDIES}

There have been several recent authoritative reviews of the time-series evidence on employment, labour supply and unemployment in the Australian labour market (see Kenyon and Wooden (1996), Lewis and Seltzer (1996), Freebaim (1997)(1998), Borland (1997a)(1997b) and Borland and Kennedy (1998)). ${ }^{16}$ These reviews are drawn upon here to provide a macroeconomic perspective on the changes over time in key labour market variables. ${ }^{17}$ The studies reviewed provide a framework in which ways of reducing the aggregate unemployment rate can be addressed. The broad areas of research can be studied with reference to the stylised model of the labour market presented in Figure 3.

In this model $\mathrm{S}$ is the aggregate labour supply curve, $\mathrm{D}$ is the textbook labour demand curve, the $\mathrm{D}-\mathrm{V}$ curve depicts measured employment (being the level of labour that firms are willing to hire (D) less vacancies (V)) and $W$ is the wage-setting curve (see, for example, Debelle and Vickery (1998), Freebaim (1998)). The wage setting curve is a reflection of the inflexibility that characterises the labour market, and is typically derived from a Phillips curve model. The employment level is determined by the intersection of the wage-setting curve and the employment curve. At wage level $\mathrm{W}_{0}$, employment is $\mathrm{N}_{\mathrm{l}}$, labour supplied is $\mathrm{N}_{2}$ and unemployment is $\mathrm{N}_{2}-\mathrm{N}_{1}$. This diagram points to the apparent importance of wages to employment and labour supply decisions, and hence to the unemployment outcome. Unemployment $\left(\mathrm{N}_{2}-\mathrm{N}_{1}\right)$ can either be analysed directly (e.g., Valentine (1993), Trivedi and Baker (1985)), or in the context of models incorporating both the demand- and supply-sides of on the market (e.g., Pissarides (1991), Debelle and Vickery (1998)). Much of the work on the aggregate rate of unemployment in Australia seems to be a by-product of economists' fascination with the Phillips curve concept.

\footnotetext{
${ }^{16}$ The reader is also directed to commentaries on unemployment in the context of the Green Paper Restoring Full Employment in the Australian Economic Review in 1994 and Economics and Labour Relations Review in 1994.

Studies which are mainly descriptive and those peripheral to the main theme of this review will not be covered.
}

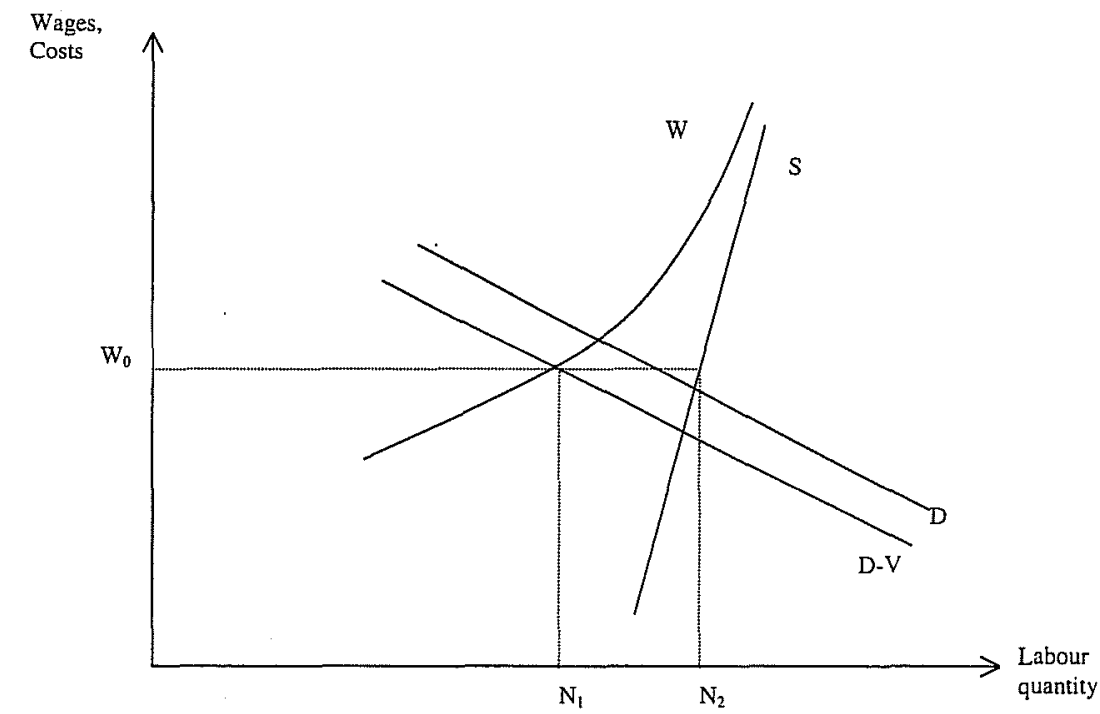

\section{Labour Demand}

The work in Australia on labour demand is summarised in Lewis and Seltzer (1996) and Freebain (1998). Table 10 provides relevant evidence. The studies overviewed in this table suggest that the long-run elasticity (the lags involve two or more years) is between -0.4 and $-0.8 .^{18}$ Moreover, Debelle and Vickery (1998), who report the -0.4 figure, find that the wage elasticity has been declining over time. This finding, based on rolling regressions of labour demand equations over 15-year windows, could be categorised as surprising. Freebairn (1998, p.119) argues that with recent moves towards a more competitive labour market, one might have expected labour demand elasticities to have increased over time. ${ }^{19}$

The studies summarised in Table 10 also report that the output elasticity is less than unity, though generally it is not significantly different from one. Also noteworthy is the

\footnotetext{
${ }^{18}$ Hamermesh (1986, p.453) suggests a range of -0.15 to -0.50 for the aggregate, long-run, constant output labour demand elasticity.

${ }^{19}$ Freebairn's conjecture is consistent with the evidence presented in a footnote in his paper. There he notes that the wage elasticity in the Russell and Tease (1991) specification rises when the data period is extended.
} 
fact that the models are based on a small set of variables, and more recent studies are less inclusive in this regard than the earlier studies. The econometric evidence accords with the common sense predictions from neo-classical theory, and the broad similarity of the Australian evidence (Table 10) with the findings in the international literature (Hamermesh (1986)) indicates a degree of robustness to the findings. Doucouliagos' (1997) meta-analysis of 21 studies on aggregate labour demand in Australia shows there is a positive association between output demand and aggregate employment and a stronger negative association between real wages and aggregate employment.

\section{Table 10}

Estimates of Aggregate Labour Demand Function, Australia

\begin{tabular}{|c|c|c|c|c|}
\hline \multirow[t]{2}{*}{ Authors } & \multirow[t]{2}{*}{ Type of Model } & \multirow[t]{2}{*}{ Data Period } & \multicolumn{2}{|c|}{ Explanatory Variables } \\
\hline & & & $\begin{array}{l}\text { Long run labour } \\
\text { cost elasticities }\end{array}$ & $\begin{array}{l}\text { Other } \\
\text { variables }\end{array}$ \\
\hline $\begin{array}{l}\text { Lewis and Kirby } \\
\text { (1988) }\end{array}$ & $\begin{array}{l}\text { Disequilibrium demand, } \\
\text { supply and partial } \\
\text { adjustment }\end{array}$ & $1967(3)-1987(1)$ & -0.78 & $\begin{array}{l}\text { Real GDP, trend } \\
\text { (productivity). } \\
\text { industrial relations. }\end{array}$ \\
\hline $\begin{array}{l}\text { Russell and } \\
\text { Tease (1991) }\end{array}$ & $\begin{array}{l}\text { Single equation, partial } \\
\text { adjustment }\end{array}$ & $1969(3)-1987(4)$ & -0.61 & $\begin{array}{l}\text { Real GDP, trend } \\
\text { (technology change). }\end{array}$ \\
\hline $\begin{array}{l}\text { Pissarides } \\
\text { (1991) }\end{array}$ & $\begin{array}{l}\text { Labour demand, supply } \\
\text { and wages }\end{array}$ & $1966(3)-1986(2)$ & -0.79 & $\begin{array}{l}\text { Cyclical effects } \\
\text { (competitiveness, fiscal } \\
\text { stance, monetary } \\
\text { stance), capital stock, } \\
\text { real interest rate. }\end{array}$ \\
\hline $\begin{array}{l}\text { Stacey and } \\
\text { Downes (1995) }\end{array}$ & $\begin{array}{l}\text { Neociassical firm } \\
\text { investment, } \\
\text { employment and } \\
\text { pricing, endogenous } \\
\text { wages }\end{array}$ & $1971(1)-1995(1)$ & -0.84 & $\begin{array}{l}\text { Real output, labour } \\
\text { productivity. }\end{array}$ \\
\hline $\begin{array}{l}\text { Dungey and } \\
\text { Pitchford (1998) }\end{array}$ & $\begin{array}{l}\text { Single equation error } \\
\text { correction model }\end{array}$ & $1984(4)-1997(1)$ & -0.40 & $\begin{array}{l}\text { Real output, real wages, } \\
\text { trend, mean hours } \\
\text { worked. }\end{array}$ \\
\hline $\begin{array}{l}\text { Debelle and } \\
\text { Vickery (1998) }\end{array}$ & $\begin{array}{l}\text { Single equation error } \\
\text { correction model }\end{array}$ & $\begin{array}{l}1978(1)-1997(4) \\
1969(1)-1997(4)\end{array}$ & $\begin{array}{l}-0.42 \\
-0.68 \\
\end{array}$ & $\begin{array}{l}\text { Real output, user cost of } \\
\text { capital, trend. }\end{array}$ \\
\hline
\end{tabular}

However, while the apparent consensus that has emerged from the aggregate labour demand studies might be encouraging, there has been some questioning of the relevance of these aggregate labour demand elasticities to debate on the unemployment problem. Chapman (1997a), for example, suggests that the particular skill mix of those in the pool of unemployment needs to be borne in mind, particularly the skills of those who have been unemployed for a relatively long time. As the mean skill level of the unemployed is below that of the employed, employers may be less responsive to any wage changes than indicated by the elasticities presented in Table 10.

Unfortunately, the attempts to obtain estimates of parameters of the demand for labour sub-groups (e.g., by skill group, age, gender and industry) provide quite varied evidence, both in Australia and internationally. The results for Australia discussed in Lewis and Seltzer (1996) and Freebairn (1998) are somewhat dated and are certainly not sufficiently robust to provide any basis for policy formation. More recent estimates in Daly et al. (1998) also lack precision. This is a major deficiency in our understanding of the way labour markets function. In this regard we might draw upon the collective wisdom of the available Australian and overseas research (e.g., Lewis and Seltzer (1996), Hamermesh (1986)) to state empirical regularities such as that low-skilled labour and capital are good substitutes, whereas high-skilled labour and capital are not good substitutes, and that lowskilled workers have a higher elasticity of demand than high-skilled workers. Values of these elasticities are, however, needed to analyse the labour market implications of many policies, particularly those that target the wage rates of the unskilled, or in comparing policies based around aggregate real wage restraint against those that lower the relative wage of the unskilled. It is almost certainly the case that estimates should be derived for the Australian labour market rather than relying on findings from research into the US labour market: the institutional arrangements are sufficiently different that the overseas evidence may not be relevant to Australia.

The relevance of research findings for the US labour market to the Australian labour market is certainly a major issue in the context of debate over the effects of minimum wages. In the minimum wage debate, the work by Card and Krueger (1994) has been seized upon by researchers who feel that the disemployment effects of real wage increases are minimal. Card and Krueger adopt a case study of individual industries approach and report that increases in the minimum wage in the fast food industry in the US might have had the surprising result of not leading to an increase in employment, and even being coincident with an increase! Their research finding has been controversial (see in particular the criticism by Welch (1995) and Hamermesh (1995)). Even if Card and Krueger (1994) are correct in their assessment for the US labour market, it is questionable how relevant their results are to the wage debate in Australia. Seltzer (1997) reviews the arguments. The main issue appears to be the different degrees to 
which award wages, are binding in the particular labour market, with minimum/award wages being binding for relatively more workers in Australia than in the US. While some commentators in Australia have used Card and Krueger's (1994) research in support of their high wage policy prescriptions (see, for example, Harcourt (1997)), most researchers argue that the employment effects of high wages, including minimum wages, are negative. Seltzer's (1997) review is most informative on this issue.

\section{Labour Supply}

Studies of labour supply have been reviewed by Kenyon and Wooden (1996) and Freebaim (1998). The benchmark study is Dunlop, Healy and McMahon (1984). They argued in 1984 (p.30) that the models of labour supply in Australia were misspecified and as a result "important policy questions such as the influence on labour supply of changes in wages.....cannot be addressed". As noted by Kenyon and Wooden (1996) there has been little statistical time-series work since then, with the accounts of changes in labour supply over time being primarily descriptive, with a focus on the different cyclical and trend components for males and females (see, for example, Borland and Kennedy (1998)).

Debelle and Vickery's (1998) study of labour supply illustrates some of the issues involved. Basically they find that only a small core of variables were statistically significant determinants of labour force participation, namely a discouraged worker variable, a variable for participation in full-time education and a time trend. Importantly, wages were not a significant determinant of labour force participation, either for males or females. The business cycle, acting via the discouraged worker effect, is argued by Freebaim (1998), and shown by Debelle and Vickery (1998), to be the more important determinant of variations in the amount of labour supplied. It is stronger for females than for males. These findings accord with the overseas evidence. They imply that in policy analysis the important supply-side influences will be via the dis/encouraged worker effect-a phenomenon that those who try to explain monthly changes in the unemployment rate will be acutely aware of.

\section{Unemployment}

Study of the determinants of the aggregate rate of unemployment has followed several distinct paths. Valentine (1993) and Trivedi and Baker (1985), for example, attempt to model the unemployment series itself. Hence, variations in the unemployment rate are related to variables for the cost of labour, real output, real unemployment benefits, structural change and demographic factors, and various adjustment variables (such as lagged dependent variables). The conclusion of Valentine's paper is instructive:

"This paper provides some statistical support for the view that the present high level of unemployment can be explained by fairly obvious economic factors. It is not an Act of God or a problem which is the unavoidable consequences of overseas events beyond our control" (p.17)

In particular, Valentine draws attention to the importance of wages and economic growth in addressing the unemployment problem. Trivedi and Baker (1985) also focus attention on these causal factors, as do the majority of the more recent contributions. As discussed earlier, empirical research in Australia has failed to establish a clear case that unemployment benefits are an important contributor to variations in unemployment.

The second set of studies that have a focus on unemployment are embedded within structural models of the labour market that encompass both demand- and supply-side considerations (e.g., Pissarides (1991), Debelle and Vickery (1998)). These studies have models for employment and labour force participation, though the specifications differ considerably. However, the conclusions of the studies converge: labour costs have a major impact on the long-run rate of unemployment. Debelle and Vickery (1998, p.260) conclude that "slower growth in real wages of 2 per cent for a year would lead to a permanent reduction in the unemployment rate of 1 percentage point.". Pissarides (1991, p.51) concludes emphatically that "The behaviour of real wages is the single most important factor in any attempt to explain the behaviour of unemployment". ${ }^{20}$

The final sets of studies to address unemployment have done so in the context of study of the natural rate of unemployment. These studies are worthy of a survey themselves. Borland and Kennedy (1998) and Borland (1997b) provide an introduction to the literature. ${ }^{21}$ They note the various approaches taken in the estimation of the natural rate (Phillips curve approach, Beveridge curve approach, structural models of

\footnotetext{
${ }^{20}$ Doucouliagos' (1997) meta-analysis of 14 studies of unemployment and real wages and output demand also indicates a positive association between real wages and the rate of unemployment.

${ }^{21}$ The paper by Groenewold and Hagger (1998) is among the latest of a large number of natural rate studies in Australia.
} 
unemployment). The yarious model specifications and approaches to estimation are also noted in Borland (1997b). The estimates of the natural rate vary across studies, and are not generally estimated precisely within studies ${ }^{22}$, though broad consensus patterns are evident. The natural rate has increased from around 2 percent in the early 1970 s to a rate of $61 / 2$ to $71 / 2$ percent in the mid-1990s. Growth in real wages in the mid-1970s is particularly evident as a contributor to the changes in the natural rate. However, it is apparent that we need a superior understanding of the determinants of the natural rate, a point made at recent conferences organised by the Industry Commission and the Reserve Bank of Australia. Possible candidates in this regard are real wages, which has been emphasised by Debelle and Vickery (1998), globalisation, rapid technological change biased against low-skilled workers, high social safety net benefits relative to wage rates, demographic changes, increases in the supply of women to the labour market, the growth in two-income households (Chiswick (1997)) and hysteresis.

\section{An Appraisal}

An outsider reading this literature might be impressed. A number of approaches to the estimation of the causes of unemployment have been taken. Emerging from the studies is a primary finding: wages and economic growth are the factors that should be focused on in discussions of unemployment. These findings have been applied in a number of exercises, including accounting for changes over time and advancing solutions to the current unemployment problem. These analyses are instructive, and a brief overview follows.

\section{Accounting for Changes Over Time}

Studies that have reviewed changes in the unemployment rate over time have involved two levels of analysis. First, the basic patterns in the data have been examined. This reveals an asymmetry: increases in unemployment, particularly during the 1980s, have been quite sharp while decreases have been taken much longer to occur (see, for example, Borland and Kennedy (1998)). This asymmetry is examined by Bodman (1998). He concludes (p.410) "The evidence is broadly suggestive of hysteresis effects in the labour market and that in recessionary periods job destruction happens rapidly and with

${ }^{22}$ Richardson (1998), for example, reports a natural rate of 6.7 percent, with a 95 percent confidence interval from 2 to 20 percent. significant intensity". The various decompositions of unemployment rate changes into demand-side and supply-side origins undertaken by Borland and Kennedy (1998) show that the extent to which unemployment rate changes can be linked to demand-side or supply-side changes has varied over the cycle. For example, increases in the unemployment rate have typically been associated with reductions in male employment rates, while decreases in the unemployment rate have generally been associated with increases in female employment rates and increases in female labour supply.

Second, there have been attempts to attribute the changes in the unemployment rate over the past three decades to causal factors. Borland (1997b) and Dawkins and Freebaim (1997) provide overviews. Several of these studies provide breakdowns of the relative importance of factors. For example, Dawkins and Freebaim (1997) suggest that reai labour costs and recession were equally important in accounting for the increase in unemployment in the early 1980s, while Ooi and Groenewold (1992) suggest that demand effects were more important than real wage effects in accounting for the changes in unemployment at this time. Given such ranges of findings, only broad statements on causes are possible. In this regard, the collective wisdom of the studies is as follows.

First, the growth in unemployment during the 1970s appears to be attributable mainly to increases in real labour costs (see, for example, Debelle and Vickery (1998)). Secondary factors that were influential during this period include the slow rate of growth, increased generosity of the unemployment benefit system, and labour supply factors. Ooi and Groenewold (1992) highlight the importance of the contributions from the increase in the labour force, though this evidence does not match that reported by Borland and Kennedy (1998) in their decomposition of the changes in the rate of unemployment into changes in labour supply and employment.

Second, the 1980s were a period of initial growth in the unemployment rate followed by a period of improvement in the labour market. The initial growth in unemployment in this period seems to be due largely to increases in real labour costs and a cyclical recession. The subsequent reduction in unemployment during the late 1980s was due to a reversal of these influences. The analyses presented in Chapman (1990) illustrate the importance of the real wage restraint under the Accord, while Ooi and Groenewold (1992) suggest that labour supply factors were also important over this period. 
The 1990s have been characterised by an initial increase in unemployment followed by a reduction in the rate of unemployment. The initial growth in unemployment appears to be attributable to recession and higher real labour costs. The recent reductions in unemployment seem to be linked to steady economic recovery. Again, consistent with the asymmetry noted during the 1990s, winding back the unemployment rate has taken far longer than required for the initial increase in the unemployment rate.

The extent to which these changes are neutral across various groups in the labour market has also been studied. Aungles, Dearden, Karmel and Ryan (1993) report that the changing employment patterns in recent decades have disadvantaged low-skilled workers. Gregory (1995) suggests that this advantage extends to older males and to the young (see also Dawkins and Kenyon (1999)). In the case of young workers, it seems that increasing education levels have not protected them from labour market adjustment. Borland and Foo (1996) report that manufacturing employment has shifted towards nonproduction, white collar and more highly skilled workers, therefore adding to the evidence of change in the composition of demand for skills over time that has increasingly disadvantaged the least skilled. Their further analyses could not uncover any particular causal factors (e.g., changes in relative wages, international trade, capital accumulation) for these changes. Dawkins and Kenyon (1999) consider whether these changes are attributable to adjustment in the wake of a lowering of the level of protection and find some support in the literature for this in respect of some manufacturing industries (in particular, for Clothing, Textiles and Footwear). However, in general, they support the view of Fahrer and Pease (1994) who argue that technical changes have been an important force in the changes in employment by industry sector. Tyers and Yang's (1997) modelling exercise also shows that technical change is associated with higher levels of unemployment. The Australian evidence on changes in employment patterns thus puts more emphasis on technical change than on changing patterns of trade (see Dawkins and Keyon (1999)). This evidence is consistent with the cross-section research which shows the least skilled to be the group most disadvantaged in the labour market.

\section{Reducing the Rate of Unemployment}

Applications of the findings from the time series studies of employment, labour supply and unemployment to the challenge of reducing the rate of unemployment have provided useful insights. Much of the discussion has centred on a pivotal role for faster economic growth and cuts in real wages. How much growth and how large a fall in real wages both remain matters for debate. Simulations of the type presented in Debelle and Vickery (1998) and Dawkins and Freebairn (1997) are suggestive of manageable wage cuts only if the unemployment target is not set too low. How the real wage reduction is to be delivered is equally a matter for debate, and creative debate at that (see Gregory (1998), Dawkins and Freebaim (1997)). Some commentators feel that significant real wage reductions are unlikely without some form of compensation for low income earners. Recent policy debate links in with these conclusions. Dawkins and Freebairn (1997), for example, argue that lower wages are a key factor in addressing the unemployment problem. They are, however, mindful of the income distribution consequences of the wage cuts that the government might be able to engineer in Australia-through holding down the wage safety net. As a widening of the income distribution is likely to be viewed as undesirable, Dawkins and Freebairn (1997) argue the case for an earned income tax credit scheme, which is a pseudo negative income tax scheme.

The level of economic growth required to be sustained to deliver an unemployment rate of around 5 percent (43/4 percent according to Table 2.1 in the 1993 Green Paper Restoring Full Employment) is generally thought to be an unlikely outcome. Coleman's (1998) analysis using a Solow-Ramsey growth model suggests that it may take about 20 years for economic growth to remove a 5 percent unemployment rate.

A number of other solutions to the unemployment problem advanced in the literature, however, do not appear to have an empirical foundation. In some cases they appear to be a residual explanation associated with concerns that the economic growth and lower real wages solutions may not be achievable. In other cases they are part of a comprehensive package of reforms thought to be necessary to make major inroads into the unemployment problem. For example, it has been proposed that microeconomic reform will deliver the growth in employment necessary to reduce unemployment. The above review of the economic growth solution would cast doubt on the efficacy of microeconomic reform as a way of reducing unemployment. Microeconomic reform, as extended to the labour market, is also held to be able to make employment protection laws less intrusive and so lower the costs of employment. This should stimulate hiring in the same way as a cut in real wages. The same microeconomic reform, however, will 
lead to job shedding, in the public sector and to structural unemployment (see Kenyon (1998)). The net benefits to the unemployed might therefore be problematic, particularly in the short term.

Work sharing, early retirement and reduced migration have also been discussed as ways of addressing the unemployment problem (see, for example, Committee on Employment Opportunities (1993)). These policies impact on the labour market via reducing the supply of labour. However they have not won a great deal of support among economists.

Work sharing and early retirement may be associated with lower levels of productivity as work performed by experienced workers is farmed out to the unemployed who are generally less skilled. In addition, sharing a fixed amount of work among a greater number of workers has a tendency to increase the fixed costs of hiring and hence the average costs of employing workers to perform a given number of hours of work. Employers will tend to respond by reducing the total hours of labour demanded. Work sharing and early retirement policies can therefore be counterproductive. The evidence presented to the Committee on Employment Opportunities (1993) did not show favourable employment effects from work sharing agreements and early retirement.

The argument that reductions in the immigrant intake will lead to lower levels of unemployment is often advanced in times of recession. The main counter-argument is that immigrants add to labour demand as well as to labour supply, and their net impact on the labour market therefore cannot be determined a priori. Refinements to this argument recognise the importance of taking into account the mix of immigrants (stream of entry, age, etc.). Most analyses, however, conclude that immigrants add as many jobs as they take, and that cuts to the immigration program are not therefore likely to lead to a reduction in the rate of unemployment.

The role of government in the policy arena is raised by Chapman (1997a). The government as employer and provider of infrastructure has also been discussed by Kenyon (1997) and Chapman (1997a). Chapman (1997a) draws attention to the government's response to the large increases in nominal wages in both 1974-75 and 1981-82 as likely causes of unemployment, and the role of monetary policy in accounting for the timing and depth of the 1990s recession. He notes the significant reduction in employment opportunities in the public sector, and suggests that this needs to be discussed when addressing the unemployment problem. Kenyon (1997) argues that government spending can have two effects. First, there is the direct effect of job creation through aggregate demand enhancement. Second, spending that provides necessary public infrastructure (e.g., transport and communications systems) can lead to higher rates of economic growth in the private sector. A range of theoretical and empirical studies that show a positive link between public infrastructure provision and rate of growth in the private sector was reviewed by Kenyon (1997).

Labour market programs have also been advanced as a way of attacking the unemployment problem. These have played a central role in much of government policy in recent decades. A brief review is therefore in order.

\section{Labour Market Programs}

Chapman (1997b, p.183) argues that "if there is an unwillingness on the part of a government to undertake radical policy variations to both the wage and social security systems, and if there is an acceptance of the macroeconomic inefficiencies associated with long-term unemployment, then targeted labour market programs have to be considered".

It is apparent that Australia has a reasonably rich tradition of intervention in the labour market through labour market programs. A number of reports evaluating various programs have been prepared, though many of these are unpublished. A number appeared in the former Bureau of Labour Market Research's Discussion Paper series. The Department of Employment, Workplace Relations and Small Business now conducts post-program monitoring. In this review three main sets of studies are covered: Kirby (1981) who covers the 1970s, Sloan and Wooden (1987) dealing with the 1980s and Kenyon (1994), Piggott and Chapman (1995) and Stromback, Dockery and Ying 1999) who address the effectiveness of the Job Compact.

Kirby (1981) outlines the range of programs in operation in Australia during the 1970s. These included job creation schemes such as the Regional Employment Development Scheme, Apprenticeship Training Support, and what Kirby categorises as "mutual adjustment measures", which comprises relocation assistance and the Commonwealth 
Employment Service. He suggests that the evaluation of these programs has had a very uneven development. Typically evaluations have been conducted on a program-byprogram basis, and have been inconclusive on the cost/benefits of particular programs.

Sloan and Wooden (1987) provide a generally negative evaluation of labour market programs in their secondary analysis. They conclude (p.162) that "Analysis of the various forms of labour market programs and of the objectives which apparently underlie them leads rapidly to the conclusion that they are (cost) ineffective means of reducing unemployment and/or increasing the future employability of the groups on which they are targeted." A theme in the Sloan and Wooden (1987) analysis is that govemments should embrace the changes to the wage and social security systems required to address the fundamental causes of unemployment.

The Job Compact, which was part of the White Paper on Employment and Growth (Working Nation) of 1994, sparked a renewed interest in the study of labour market programs. The Job Compact entailed an increase in resources devoted to labour market programs, and these were targeted on the long-term unemployed. It included an employment placement for those unemployed for greater than 18 months. Kenyon (1994) and Piggott and Chapman (1995) are more deliberate than previous researchers in sketching the range of likely effects of labour market programs. They draw attention to two main effects of such interventions. The first is the net employment effect, made up of the positive effect of the numbers subsidised, and the negative effects of who would have gained employment even without the labour market program (termed a deadweight loss), and those displaced from jobs by program participants. The second is the impact on future employability, both among those participating in a program, and those who do not participate in a program who nevertheless might have their future employability altered by displacement.

Kenyon's (1994) review of the empirical evidence for both macroeconomic and microeconomic effects of labour market programs leads him to a largely negative conclusion. Thus he argues (p.293) "The evidence suggests that the likely net employment generating effects of the Job Compact are problematic. Although there is plenty of evidence of net employment generation through Active Labour Market
Programs, there is also plenty of evidence of offsetting and negative effects". Dawkins and Freebaim (1997) are sceptical of the impact that labour market programs can have.

Piggott and Chapman (1995), however, offer a much more positive appraisal of labour market programs. They outline a transition flow model of Australian unemployment, and then impose the employment programs that form the Job Compact on this. In this model, entrants into long-term unemployment are transferred to Job Compact employment. At the completion of this employment, the program participants either remain employed (i.e., the program is effective) or re-enter the pool of unemployment as a new entrant. Displacement effects are also modelled by reducing the rate of job finding by the shortterm unemployed. As wage subsidy (e.g., JobStart) and job creation (e.g., New Work Opportunities) schemes differ appreciably in their labour market effects ${ }^{23}$, information on the effectiveness and displacement effects of each of these types of programs are derived from the Australian and overseas literature. For plausible values of these labour market effects, the opportunity cost of the Job Compact was calculated to be modest, with Piggott and Chapman's (1995) neutral estimate indicating a cost saving to the government, and their conservative estimate being two-thirds of the estimated official cost of the Job Compact.

Stromback et al. (1999) report evidence from the Australian Bureau of Statistics' Survey of Employment and Unemployment Patterns to the effect that both Wage Subsidy programs and Employment Training programs (which include New Work Opportunities) are associated with reductions in the probability of being unemployed, with the impact of the latter programs being more important in this regard. This finding contrasts with much of the literature, suggesting there is still considerable research required to understand the workings of labour market programs.

\section{CONCLUSION}

Reading the unemployment literature in Australia invokes mixed reactions. First, one is struck by the apparent concern of economists over the unemployment problem. It is widely acknowledged that "unemployment should properly be regarded as the most significant economic and social problem currently facing policy makers in Australia"

For information on the extent of the differences, consult Table 1 in Piggott and Chapman (1995). 
(Borland and Kennedy (1998, p.69)). Second, it is apparent that there are many research areas where broad agreement has been reached. Of particular note are the cross-sectional studies of the factors contributing to a high probability of unemployment, and estimates of the aggregate labour demand wage and output elasticities. There is also broad agreement that lower real wages and stronger economic growth should form important components of any solution to the unemployment problem. Given the state of our knowledge, Gregory's (1998) words, “...shouldn't we try harder”, should ring in any reader's ears.

Two reasons why we do not try harder are highlighted in the literature. First, as proposed solutions have both winners and losers, governments either do not have the political will or do not perceive the need, to favour those who would gain from policies that would reduce the rate of unemployment (Kenyon (1998)). Second, we are unsure of how to deliver the real wage cuts (maybe 5-10 percent) and rates of economic growth (close to 5 percent) discussed as ways to reduce the rate of unemployment to about 5 percent.

However, we should know the direction in which we should be heading. One can contemplate broad packages of reforms such as that advocated by Dawkins (1998). Substantial reforms such as the earned income tax credits advocated by Dawkins and Freebaim (1997) need to be given serious consideration if we are to make major inroads into the unemployment problem. Certainly one should avoid policies that have the potential to accentuate the unemployment problem. It is disappointing that the recent debate on youth wages shows how difficult it will be to tackle the unemployment problem. ${ }^{24}$

\section{Appendix A}

Table A1

Summary of Australian Cross-sectional Studies of Unemployment

\begin{tabular}{lll}
\hline Authors & Data & $\begin{array}{c}\text { Estimation } \\
\text { Technique }\end{array}$ \\
\hline Australian & 1983 and 1984 & Logit \\
Institute of & General & \\
Multicultural & Surveys, 1976 \\
Affairs & and 1981 \\
(1985) & Censuses of & \\
& Population and & \\
& Housing &
\end{tabular}
Independent

Gariables Major Findings

qualifications, age, marital status, English proficiency, birthplace
of individual, birthplace of individual, birthplace
of parents, period of residence, geographica location.

\begin{tabular}{|c|c|}
\hline $\begin{array}{l}\text { Beggs and } \\
\text { Chapman } \\
\text { (1988) }\end{array}$ & $\begin{array}{l}\text { 1981 Census of } \\
\text { Population and } \\
\text { Housing }\end{array}$ \\
\hline & \\
\hline $\begin{array}{l}\text { Garde and } \\
\text { Vipond }\end{array}$ & $\begin{array}{l}\text { Population and } \\
\text { Housing }\end{array}$ \\
\hline & \\
\hline
\end{tabular}

Australian education, Australian labour market experience. overseas labour mark experience, marital
status (presence of status (presence of
spouse), English proficiency.

\section{Gender, education, age, English proficiency,} race, birthplace of
father, period of residence, geograph location, mobility, father's education, father's occupation, father's unemploymen status, father's labour force status, mother's education, mother's cecupaton, moth's mother's labour force status, siblings' unemployment sta unemployment
family income.

Education, age, marital status, English
High unemployment rates are

ment rates are associated with being female, single,
living in a non-metropolitan area, and living in a non-metropolitan area, and
having poor English skills. The

overseas born residing in Australia

less than one year have a higher rate of unemployment than those who had been in Australia for 10 or more years. Results from 1983 General Survey: gender, age and education hav probability of being unemployed. of individual, period of residence, geographic location, parents' education, age of youngest child, father's income, family income.

${ }^{24}$ Many of the problems of the current time seem captured by Valentine (1993, p.18): "A misplaced concern for - social justice has led us to adopt policies which have created unemployment, especially among lower income
Educational attainment and marital
status have the strongest impacts on unemployment. Migrants from English-speaking countries have lower probabilities of unemployment than non-English speaking

Unemployment rates are much higher among teenagers of sole-parent families than among other teenagers. In the case of teenagers living with their mothers only, high

themployment could be attributed to lived with both parents from lowincome families also experienced high rates of unemployment. Moreover, teenagers living with parents who have low levels of education, who worked in 'working class' occupations or who unemployed. Families living in to be quality or rental accommodations are more likely to have teenagers who are unemployed.

Education, marital status, birthplace and period of residence are importa determinants of labour market presence of young children and the level of the husband's income are important determinants of femal labour market outcomes. For teenagers (15-19 years old), the most outcomes are age locality far mark income and the level of education of parents of the same sex. 


\begin{tabular}{|c|c|c|c|c|}
\hline Authors & Data & $\begin{array}{l}\text { Estimation } \\
\text { Technique }\end{array}$ & $\begin{array}{l}\text { Independent } \\
\text { Variables }\end{array}$ & Major Findings \\
\hline $\begin{array}{l}\text { Harris } \\
\text { (1996) }\end{array}$ & $\begin{array}{l}1985 \\
\text { Australian } \\
\text { Longitudinal } \\
\text { Survey }\end{array}$ & Probit & $\begin{array}{l}\text { Education, age, marital } \\
\text { status, disability, race, } \\
\text { geographical location, } \\
\text { nature of occupancy, } \\
\text { partner's employment } \\
\text { stauss, number of } \\
\text { children, unemployment } \\
\text { benefit. }\end{array}$ & $\begin{array}{l}\text { Education, age and financial } \\
\text { commitments have positive influences } \\
\text { on employment prospects for } \\
\text { individuals. Disabled persons are } \\
\text { disadvantaged in the workplace. } \\
\text { Women are less likely to be employed } \\
\text { if they have children. Other factors } \\
\text { which affect the incidence of } \\
\text { unemployment include marital status, } \\
\text { geographical location and the nature of } \\
\text { occupancy. }\end{array}$ \\
\hline $\begin{array}{l}\text { Inglis and } \\
\text { Stromback } \\
\text { (1986) }\end{array}$ & $\begin{array}{l}1981 \text { Census of } \\
\text { Population and } \\
\text { Housing }\end{array}$ & Logit & $\begin{array}{l}\text { Education, attending an } \\
\text { educational institution, } \\
\text { qualification acquired } \\
\text { abroad, age, marital } \\
\text { status, English } \\
\text { proficiency, birthplace } \\
\text { of individual, period of } \\
\text { residence, geographical } \\
\text { location, mobility. } \\
\text { nature of occupancy, } \\
\text { relationship to fampily } \\
\text { head, number of } \\
\text { children. }\end{array}$ & $\begin{array}{l}\text { The high rate of unemployment among } \\
\text { migrants can be attributed to the lack } \\
\text { of English language proficiency. } \\
\text { birthplace and period of residence. } \\
\text { For example, recently arrived miggrants } \\
\text { have a higher unemployment rate } \\
\text { relative to the Australian borm. } \\
\text { However, the migrant/native born } \\
\text { unemployment rate differential } \\
\text { decreases with duration of residence in } \\
\text { Australia. }\end{array}$ \\
\hline Jones (1990) & $\begin{array}{l}1986 \text { Census of } \\
\text { Population and } \\
\text { Housing }\end{array}$ & Logit & $\begin{array}{l}\text { Education, } \\
\text { qualifications, labour } \\
\text { market experience, } \\
\text { marital status, English } \\
\text { proficiency. }\end{array}$ & $\begin{array}{l}\text { Education, labour market experience, } \\
\text { marital status and proficiency in } \\
\text { English enhance the employment } \\
\text { opportunities for Aborigines. } \\
\text { However, the impact of post-school } \\
\text { qualifications on the unemployment } \\
\text { probability is much larger than that of } \\
\text { schooling. Women are less likely to } \\
\text { be unemployed as they get older. } \\
\text { Aborigines experienced a much higher } \\
\text { rate of unemployment than Anglo- } \\
\text { Celts. }\end{array}$ \\
\hline Jones (1992) & $\begin{array}{l}1986 \text { Census of } \\
\text { Population and } \\
\text { Housing }\end{array}$ & Logit & $\begin{array}{l}\text { Australian education, } \\
\text { overseas education } \\
\text { qualification acquired in } \\
\text { Australia, qualification } \\
\text { acquired abroad, } \\
\text { Australian labour } \\
\text { market experience, } \\
\text { overseas labour market } \\
\text { experience, marital } \\
\text { starus, English } \\
\text { proficiency, birthplace } \\
\text { of individual, Australian } \\
\text { citizenship. }\end{array}$ & $\begin{array}{l}\text { Education, qualifications, labour } \\
\text { market experience, marital status, } \\
\text { proficiency in English and possessing } \\
\text { Australian citizzenship siggificantly } \\
\text { affect the probability of being } \\
\text { unemployed for migrants. Overseas } \\
\text { qualifications and labour market } \\
\text { experience obtained in Australia have } \\
\text { a stronger impact on unemployment } \\
\text { than those obtained in the country of } \\
\text { origin. }\end{array}$ \\
\hline
\end{tabular}

\begin{tabular}{|c|c|c|c|c|}
\hline Authors & Data & $\begin{array}{l}\text { Estimation } \\
\text { Technique } \\
\end{array}$ & $\begin{array}{l}\text { Independent } \\
\text { Variables }\end{array}$ & Major Findings \\
\hline $\begin{array}{l}\text { Junankar and } \\
\text { Wood (1992) }\end{array}$ & $\begin{array}{l}1985 \\
\text { Australian } \\
\text { Longirudinal } \\
\text { Survey }\end{array}$ & $\begin{array}{l}\text { Multinomial } \\
\text { logit }\end{array}$ & $\begin{array}{l}\text { Education, age, labour } \\
\text { market experience, } \\
\text { marital status, health } \\
\text { stataus, Englisht } \\
\text { proficiency, birthplace } \\
\text { of individual, } \\
\text { geographical location, } \\
\text { occupation, looking for } \\
\text { work in previous year, } \\
\text { number of } \\
\text { unemployment spells in } \\
\text { one year, fired from last } \\
\text { jobu unemployment } \\
\text { duration greater than } \\
\text { one year, income, union, } \\
\text { membership. }\end{array}$ & $\begin{array}{l}\text { Evidence of scarring. Males who had } \\
\text { been fired from their last job are more } \\
\text { likely to face recurrents spells of } \\
\text { unemployment. Migrants, non-union } \\
\text { members, or individuals who had low } \\
\text { paid work in the past are more likely } \\
\text { to face recurrent spells of } \\
\text { unemployment. }\end{array}$ \\
\hline $\begin{array}{l}\text { Le and } \\
\text { Miller } \\
\text { (1999) }\end{array}$ & $\begin{array}{l}\text { Survey of } \\
\text { Employment } \\
\text { and } \\
\text { Unemployment } \\
\text { Patterns }\end{array}$ & Logit & $\begin{array}{l}\text { Gender, education, age, } \\
\text { marital status, disability, } \\
\text { English proficiency, } \\
\text { Indigenous status, } \\
\text { birthplace of individual, } \\
\text { period of residence, } \\
\text { geograptical location, } \\
\text { socioeconomic index, } \\
\text { mobility, previous work, } \\
\text { looking for work, } \\
\text { looking for work since } \\
\text { first left fulll-time } \\
\text { education, family } \\
\text { member unemployed, } \\
\text { family member } \\
\text { unemployed } 12 \text { months } \\
\text { or more. }\end{array}$ & $\begin{array}{l}\text { Evidence of scarring. Individuals who } \\
\text { spent the previous year looking for } \\
\text { work while not working are more } \\
\text { likely to be unemployed in the current } \\
\text { period. Similarly, those who spent a } \\
\text { long period of time looking for work } \\
\text { since they first left full-time education } \\
\text { have a relatively high probability of } \\
\text { being unemployed. Individuals who } \\
\text { have a family member who had been } \\
\text { unemployed are more likely to be } \\
\text { unemployed themselves. Other factors } \\
\text { that affect the probability of being } \\
\text { unemployed include education, age, } \\
\text { marital status, English proficiency and } \\
\text { disability. }\end{array}$ \\
\hline $\begin{array}{l}\text { Miller } \\
\text { (1986) }\end{array}$ & $\begin{array}{l}1981 \text { Census of } \\
\text { Population and } \\
\text { Housing }\end{array}$ & Logit & $\begin{array}{l}\text { Gender, education, } \\
\text { school leaving age, } \\
\text { attending an educational } \\
\text { institution, age, marital } \\
\text { status, English } \\
\text { proficiency, period of } \\
\text { residence. }\end{array}$ & $\begin{array}{l}\text { The probability of being unemployed } \\
\text { is significantly influenced by gender, } \\
\text { education, age, marital status. English } \\
\text { proficiency and period of residence. } \\
\text { Foreign-bom workers experienced. } \\
\text { higher unemployment than Austral ian- } \\
\text { borm workers. Proficiency in English } \\
\text { is very important to migrants' relative } \\
\text { labour market success. For many } \\
\text { birthplace groups, additional years of } \\
\text { education are not associated with } \\
\text { reduction in the rate of unemployment. } \\
\text { Recent arrivals have a higher } \\
\text { unemployment rate than long-term } \\
\text { settlers for most bisthplace groups. } \\
\text { The relative disadvantage of recent } \\
\text { arrivals is greater among } 20-24 \text { years } \\
\text { old than among teenagers. }\end{array}$ \\
\hline $\begin{array}{l}\text { Miller } \\
(1990)\end{array}$ & $\begin{array}{l}1986 \text { Census of } \\
\text { Population and } \\
\text { Housing }\end{array}$ & Logit & $\begin{array}{l}\text { Education, } \\
\text { qualifications, age, } \\
\text { marital status, } \\
\text { geographical location, } \\
\text { presence and age of } \\
\text { children. }\end{array}$ & $\begin{array}{l}\text { Aborigines experienced a much higher } \\
\text { rate of unemployment than non- } \\
\text { Aborigines. However, the major part } \\
\text { of the Aboriginal/non-Aboriginal } \\
\text { unemployment rate differential cannot } \\
\text { be explained by the skills of the two } \\
\text { groups. There is also evidence of } \\
\text { concentration of unemployment within } \\
\text { family groups. }\end{array}$ \\
\hline
\end{tabular}




\begin{tabular}{|c|c|c|c|c|}
\hline Authors & Data & $\begin{array}{l}\text { Estimation } \\
\text { Technique } \\
\end{array}$ & $\begin{array}{l}\text { Independent } \\
\text { Variables }\end{array}$ & Major Findings \\
\hline $\begin{array}{l}\text { Miller } \\
\text { (1998) }\end{array}$ & $\begin{array}{l}1991 \text { Census of } \\
\text { Population and } \\
\text { Housing }\end{array}$ & Logit, OLS & $\begin{array}{l}\text { Gender, education, age, } \\
\text { marital status, English } \\
\text { proficiency, race, } \\
\text { birthplace of individual, } \\
\text { period of residence, } \\
\text { geographical location, } \\
\text { mobility, nature of } \\
\text { dwelling, household } \\
\text { type, father's birthplace, } \\
\text { father's education, } \\
\text { father's qualification, } \\
\text { father's unemployment } \\
\text { status, father's labour } \\
\text { force status, mother's } \\
\text { education, mother's } \\
\text { qualification, mother's } \\
\text { unemployment status, } \\
\text { mother's labour force, } \\
\text { status, family income. }\end{array}$ & $\begin{array}{l}\text { The unemployment status of family } \\
\text { mernbers is a highly significant } \\
\text { determinant of the incidence of } \\
\text { unemployment of inidividuals in the } \\
\text { youth labour market. Variables } \\
\text { describing the unemployment status of } \\
\text { family members are associated with } \\
\text { unemployment effects greater in } \\
\text { magnitude than those associated with } \\
\text { personal characteristics. Those with a } \\
\text { high unemployment rate include } \\
\text { recently arrived migrants, young } \\
\text { people with unemployed parents or } \\
\text { unemployed siblingss, and young } \\
\text { people in low family income } \\
\text { households. }\end{array}$ \\
\hline $\begin{array}{l}\text { Miller and } \\
\text { Neo (1997) }\end{array}$ & $\begin{array}{l}1991 \text { Census of } \\
\text { Population and } \\
\text { Housing }\end{array}$ & Logit & $\begin{array}{l}\text { Education, } \\
\text { qualifications, age, } \\
\text { marital status (spouse } \\
\text { present, spouse } \\
\text { unemployed), English } \\
\text { proficiency, birthplace } \\
\text { of individual, period of } \\
\text { residence, geographical } \\
\text { location, number of } \\
\text { children. }\end{array}$ & $\begin{array}{l}\text { Education, qualification, age, English } \\
\text { proficiency and period of residence are } \\
\text { significant determinants of } \\
\text { employment success. If migrants' } \\
\text { marketable characteristics were } \\
\text { rewarded in the labour market in the } \\
\text { same way that the characteristics of } \\
\text { Australian-bom workers are rewarded, } \\
\text { then migrants would have a lower } \\
\text { unemployment rate than that of the } \\
\text { Australian born. However, the } \\
\text { potential advantage migrants have } \\
\text { over the Australian borm is offset by } \\
\text { unjustifiable factors. }\end{array}$ \\
\hline $\begin{array}{l}\text { Miller and } \\
\text { Volker } \\
\text { (1987) }\end{array}$ & $\begin{array}{l}1985 \\
\text { Australian } \\
\text { Longitudinal } \\
\text { Survey }\end{array}$ & Logit & $\begin{array}{l}\text { Education, } \\
\text { qualifications, age, } \\
\text { marital status, English } \\
\text { proficiency, birthplace } \\
\text { of individual, period of } \\
\text { residence, geographical } \\
\text { location, previous } \\
\text { labour market success } \\
\text { (unemployed long- } \\
\text { term), partner's } \\
\text { unemployment status, } \\
\text { number of children, age } \\
\text { of youngest child. }\end{array}$ & $\begin{array}{l}\text { Education, age, marital status and } \\
\text { geographical location are significant } \\
\text { determinants of unemployment. There } \\
\text { is evidence of scarring: Individuals } \\
\text { who experienced substantial } \\
\text { unemployment in one year are very } \\
\text { much more likely to be unemployed in } \\
\text { the subsequent year. }\end{array}$ \\
\hline Ross (1990) & $\begin{array}{l}1986-87 \\
\text { Survey of } \\
\text { Working Age } \\
\text { Aborigines in } \\
\text { NSW }\end{array}$ & Probit & $\begin{array}{l}\text { Gender, education, age, } \\
\text { labour market } \\
\text { experience, marital } \\
\text { status, geographical } \\
\text { location, participated in } \\
\text { labour market programs, } \\
\text { income other than } \\
\text { earnings and social } \\
\text { security benefits. }\end{array}$ & $\begin{array}{l}\text { The strongest determinants of } \\
\text { employment status are education, } \\
\text { recent work experience, labour market } \\
\text { programs experience and geographical } \\
\text { location. }\end{array}$ \\
\hline
\end{tabular}

\begin{tabular}{|c|c|c|c|c|}
\hline Authors & Data & $\begin{array}{l}\text { Estimation } \\
\text { Technique }\end{array}$ & $\begin{array}{l}\text { Independent } \\
\text { Variables } \\
\end{array}$ & Major Findings \\
\hline Ross (1993) & $\begin{array}{l}1986-87 \\
\text { Survey of } \\
\text { Working Age } \\
\text { Aborigines in } \\
\text { NSW }\end{array}$ & Probit & $\begin{array}{l}\text { Gender, education, age, } \\
\text { labour market } \\
\text { experiense, marital } \\
\text { status, geographical } \\
\text { location, participated in } \\
\text { labour market programs, } \\
\text { income other than } \\
\text { earnings and social } \\
\text { security benefits. }\end{array}$ & $\begin{array}{l}\text { Acquisition of human capital (e.g., } \\
\text { education, labour market experience. } \\
\text { participating in formal labour market } \\
\text { programs) are important to the } \\
\text { employment success of Aborigines. }\end{array}$ \\
\hline $\begin{array}{l}\text { Wooden } \\
\text { (1991) }\end{array}$ & $\begin{array}{l}1987 \text { Labour } \\
\text { Force Status } \\
\text { and other } \\
\text { Characteristics } \\
\text { of Migrants }\end{array}$ & $\begin{array}{l}\text { Multinomial } \\
\text { logit }\end{array}$ & $\begin{array}{l}\text { Post-school } \\
\text { qualifications, age, pre- } \\
\text { migration occupation, } \\
\text { did not have a job prior } \\
\text { to migration, birthplace } \\
\text { of individual, refugee } \\
\text { status, period of } \\
\text { residence, geographical } \\
\text { location, family } \\
\text { situation (single, no } \\
\text { dependents), presence of } \\
\text { family members in } \\
\text { Australia prior to } \\
\text { migration. }\end{array}$ & $\begin{array}{l}\text { Among the new anrivals, refugees } \\
\text { have employment probabilities of } \\
\text { around } 20 \text { percentage points lower } \\
\text { than comparable non-refugees. While } \\
\text { this difference has narrowed over } \\
\text { time, for males, it is never eliminated } \\
\text { completely. The persistence of the } \\
\text { differential in employment probability } \\
\text { is not the result of discrimination but } \\
\text { rather because refugees have relatively } \\
\text { poor English skitls. }\end{array}$ \\
\hline
\end{tabular}


Aungles, P., L. Dearden, T. Karmel and C. Ryan, (1993). "Through a Rear-View Mirror Darkly: Occupational Change, 1971-1986", Australian Bulletin of Labour, Vol. 19, No. 2, pp.97-113

Australian Bureau of Statistics, (1998). 1996 Census of Population and Housing: Aboriginal and Torres Strait Islander People, Cat no. 2034.0.

Australian Bureau of Statistics, (1999a). Labour Force, Australia, November, Cat no 6203.0 .

Australian Bureau of Statistics, (1999b). Transition from Education to Work, May, Cat no. 6227.0 .

Australian Institute of Multicultural Affairs, (1985). Reducing the Risk: Unemployed Migrant Youth and Labour Market Programs, Australian Institute of Multicultural Affairs, Melbourne.

Beggs, J.J. and B.J. Chapman, (1988). "The International Transferability of Human Capital: Immigrant Labour Market Outcomes in Australia", in P. Miller and L. Baker (Eds.), The Economics of Immigration: Proceedings of a Conference, Australian Government Publishing Service, Canberra, pp.143-157.

Bodman, P.M., (1998). "Asymmetry and Duration Dependence in Australian GDP and Unemployment", Economic Record, Vol. 74, No. 227, pp.399-411.

Bodman, P.M. and C. Maultby, (1996). "Crime, Punishment and Deterrence in Australia: A Further Empirical Investigation", Department of Economics, University of Queensland, Discussion Paper No. 196.

Borjas, G., (1985). "Assimilation, Changes in Cohort Quality and the Earnings of Immigrants", Journal of Labor Economics, Vol. 3, No. 4, pp.463-489.

Borland, J., (1997a). "Change in the Supply of Labour in Australia", in Industry Commission, Changing Labour Markets: Prospects for Productivity Growth, Industry Commission, Melbourne, pp.19-44.

Borland, J., (1997b). "Unemployment in Australia-Prospects and Policies: An Overview", Australian Economic Review, Vol. 30, No. 4, pp.391-404.

Borland, J. and L. Foo, (1996). "The Composition of Employment in Manufacturing Industry", Joumal of Industrial Relations, Vol. 38, No. 3, pp.442-466.

Borland, J. and S. Kennedy, (1998). "Dimensions, Structure and History of Australian Unemployment", in G. Debelle and J. Borland (Eds.), Unemployment and the Australian Labour Market, Reserve Bank of Australia, Sydney, pp.68-99.

Bradbury, B., (1993). "Family Assistance, Replacement Rates and the Unemployment of Married Men", Australian Bulletin of Labour, Vol. 19, No. 2, pp.114-132.
Bradbury, B., P. Garde and J. Vipond, (1986). "Youth Unemployment and Intergenerational Immobility", Joumal of Industrial Relations, Vol. 28, No. 2, pp.191-210.

Brooks, C. and P.A. Volker, (1985). "Labour Market Success and Failure: An Analysis of the Factors Leading to the Workforce Destinations of the Australian Population", in P.A. Volker (Ed.), The Structure and Duration of Unemployment in Australia, Australian Government Publishing Service, Canberra, pp.43-71.

Brooks, C and P. Volker, (1986). "The Probability of Leaving Unemployment: The Influence of Duration, Destination and Demographics", Economic Record, Vol 62 , No. 178 , pp.296-309.

Card, D. and A.B. Krueger, (1994). "Minimum Wages and Employment: A Case Study of the Fast-Food Industry in New Jersey and Pennsylvania", American Economic Review, Vol. 84, No. 4, pp.772-793.

Chapman, B., (1990). "The Labour Market", in S. Grenville (Ed.), The Australian Macroeconomy in the 1980s, Reserve Bank of Australia, Sydney, pp.7-65.

Chapman, B., (1997a). "Comment on "Towards Full Employment", Australian Economic Review, Vol. 30, No. 4, pp.418-420.

Chapman, B., (1997b). "Labour Market Programs", in Industry Commission, Changing Labour Markets: Prospects for Productivity Growth, Workshop Proceedings, Industry Commission, Melbourne, pp.177-189.

Chapman, BJ and PN Smith, (1992) "Predicting the Long-term Unemployed: A Primer for the Commonwealth Employment Service", in R.G. Gregory and T. Karmel (Eds.), Youth in the Eighties: Papers from the Australian Longitudinal Survey Research Project, Department of Employment, Education and Training, Canberra, pp.263-281.

Chiswick, B.R. (1997). "Discussion of John Freebairn's 'Unemployment", in Industry Commission, Changing Labour Markets: Prospects for Productivity Growth Industry Commission, Melbourne, pp.146-149.

Coleman, W., (1998). "Should We Wait to 'Grow Out of' Unemployment?: The Implications of a Neoclassical Calibration Exercise", Economic Record, Vol. 74 No. 225 , pp. $162-169$

Committee on Employment Opportunities, (1993). Restoring Full Employment: A Discussion Paper, Australian Government Publishing Service, Canberra.

Daly. A., D. Nguyen-Hong, D. Eldridge, O. Gabbitas, and P. McCalman, (1998). "Youth Wages and Employment", Productivity Commission Staff Research Paper, AusInfo, Canberra. 
Dawkins, P., (1998). "Solutions to Unemployment and Avoiding the 'Diabolical Trade Off': A Discussion", in G. Debelle and J. Borland (Eds.), Unemployment and the Australian Labour Market, Reserve Bank of Australia, Sydney, pp.309-326.

Dawkins, P. and J. Freebaim, (1997). "Towards Full Employment", Australian Economic Review, Vol. 30, No. 4, pp.405-417.

Dawkins, P. and P. Kenyon, (1999). "The Labour Market and International Competitiveness", mimeo, Curtin University of Technology.

Debelle, G. and J. Vickery, (1998). "The Macroeconomics of Australian Unemployment", in G. Debelle and J. Borland (Eds.), Unemployment and the Australian Labour Market, Reserve Bank of Australia, Sydney, pp.235-265.

Debelle, G. and J. Vickery, (1999). "Labour Market Adjustment: Evidence on Interstate Labour Mobility”, Australian Economic Review, Vol. 32, No. 3, pp.249-263.

Department of Employment, Education, Training and Youth Affairs (1998). Job Seeker Classification Instrument, Department of Employment, Education, Training and Youth Affairs, Canberra.

Doucouliagos, C., (1997). "The Aggregate Demand for Labour in Australia: A MetaAnalysis", Australian Economic Papers, Vol. 36, No. 69, pp.224-242.

Duleep, H.O. and M.C. Regets, (1997). "The Decline in Immigrant Entry Earnings: Less Transferable Skills or Lower Ability", Quarterly Review of Economics and Finance, Vol. 37 (Special Issue on Immigration), pp.189-208.

Dungey, M. and J. Pitchford, (1998). "Prospects for Output and Employment Growth With Steady Inflation", in G. Debelle and J. Borland (Eds.), Unemployment and the Australian Labour Market, Reserve Bank of Australia, Sydney, pp.208-234.

Dunlop, Y., T. Healy and P.J. McMahon, (1984). "Australian Models of Labour Force Participation: A Critical Review", in A.J. Kaspura (Ed.), Labour Force Participation in Australia: The Proceedings of a Conference, Australian Government Publishing Service, Canberra, pp.17-38.

Fahrer, J. and A. Pease, (1994). "International Trade and the Australian Labour Market", in P. Lowe and J. Dwyer (Eds.), International Integration of the Australian Economy, Reserve Bank of Australia, Sydney, pp.177-224.

Flatau, P., R. Petridis and G. Wood, (1995). Immigrants and Invisible Underemployment, Australian Government Publishing Service, Canberra.

Freebairn, J., (1997). "Unemployment", in Industry Commission, Changing Labour Markets: Prospects for Productivity Growth, Industry Commission, Melbourne, pp.121-145.
Freebaim, J., (1998). "Microeconomics of the Australian Labour Market", in G. Debelle and J. Borland (Eds.), Unemployment and the Australian Labour Market, Reserve Bank of Australia, Sydney, pp.110-133.

Graetz, B., (1992). "Health Consequences of Employment and Unemployment", in R.G Gregory and T. Karmel (Eds.), Youth in the Eighties: Papers from the Australian Longitudinal Survey Research Project, Department of Employment, Education and Training, Canberra, pp.352-371.

Gregory, R.G., (1995). "Higher Education Expansion and Economic Change", Australian Bulletin of Labour, Vol. 21, No. 4, pp.295-322.

Gregory, R.G., (1998). "What Do we Mean by an Unemployment Solution", in G. Debelle and J. Borland (Eds.), Unemployment and the Australian Labour Market, Reserve Bank of Australia, Sydney, pp.329-341.

Gregory, R.G. and B. Hunter, (1995). "The Macro Economy and the Growth of Ghettos and Urban Poverty in Australia", Centre for Economic Policy Research, The Australian National University, Discussion Paper No. 325.

Gregory, R.G. and B. Hunter, (1996). "Increasing Regional Inequality and the Decline of Manufacturing", in P. Sheehan, B. Grewal and M. Kumnick (Eds.), Dialogues on Australia's Future, Centre for Strategic Economic Studies, pp.307-324.

Gregory, R.G. and P.R. Patterson, (1980). "The Impact of Unemployment Benefit Payments on the Level and Composition of Unemployment in Australia", Centre for Economic Policy Research, The Australian National University, Discussion Paper No. 11.

Groenewold, N. and A.J. Hagger, (1998). "The Natural Unemployment Rate in Australia Since the Seventies", Economic Record, Vol. 74, No. 224, pp.24-35.

Hamermesh, D.S., (1986). "The Demand for Labor in the Long Run", in O.C. Ashenfelter and R. Layard (Eds.), Handbook of Labor Economics, Vol. 1, North Holland, New York, pp.429-471.

Hamermesh, D.S., (1995). "Review Symposium: Myth and Measurement: The New Economics of the Minimun Wage: Comment", Industrial and Labor Relations Review, Vol. 48, No. 4, pp.835-838.

Harcourt, T., (1997). "The Economics of the Living Wage", Australian Economic Review, Vol. 30, No. 2, pp.194-203.

Harris, M.N., (1996). "Modelling the Probability of Youth Unemployment in Australia", Economic Record, Vol. 72, No. 217, pp.118-129.

Inglis, P.A. and T. Stromback, (1986). "Migrants' Unemployment: The Determinants of Employment Success", Economic Record, Vol. 62, No. 178, pp.310-324. 
Jones, F.L., (1990). "Economic Status of Aboriginal and Other Australians: A Comparison", in J.C. Altman (Ed.), Aboriginal Employment Equity by the Year 2000, Centre for Aboriginal Economic Policy Research, Australian National University, Canberra, pp.27-46.

Jones, F.L., (1992). Sex and Ethnicity in the Australian Labour Market: The Immigrant Experience, Australian Bureau of Statistics Occasional Paper, Cat no. 6252.0.

Junankar, P.N. and M. Wood, (1992). "The Dynamics of Youth Unemployment: A Preliminary Analysis of Recurrent Unemployment", in R.G. Gregory and T. Karmel (Eds.), Youth in the Eighties: Papers from the Australian Longitudinal Survey Research Project, Department of Employment, Education and Training, Canberra, pp.282-304

Kenyon, P., (1994). "The Job Compact: What Does the International Evidence on Active Labour Market Policies Suggest About the Likelihood of Job Success", Australian Bulletin of Labour, Vol. 20, No. 4, pp.272-297.

Kenyon, P., (1997). "Infrastructure Spending and Unemployment: Government Responsibility for Growth and Jobs", Australian Economic Review, Vol 30, No. 4, pp. 421-432.

Kenyon, P., (1998). "Discussion of 'Dimensions, Structure and History of Australian Unemployment' by Jeff Borland and Steven Kennedy", in G. Debelle and J. Borland (Eds.), Unemployment and the Australian Labour Market, Reserve Bank of Australia, Sydney, pp.100-108.

Kenyon, P. and M. Wooden, (1996). 'Labour Supply", in K. Norris and M. Wooden (Eds.), The Changing Australian Labour Market, Australian Governmen Publishing Service, Canberra, pp. 15-38.

Kilpatrick, S. and B. Felmingham, (1996). "Labour Mobility in the Australian Regions", Economic Record, Vol. 72, No. 218, pp.214-223.

Kirby, P.E.F., (1981). "An Overview of Australian Experience with Manpowe Programs", in C.E. Baird, R.G. Gregory and F.H. Gruen (Eds.), Youth Unemployment, Education and Training, Centre for Economic Policy Research, The Australian National University, Canberra, pp.4.4-4.37.

Knights, S., (1999). "Dynamic Relationships Within the Australian Labour Market: Heterogeneity and State Dependence", unpublished Master of Commerce Research Report, Department of Economics, The University of Melbourne.

Layard, R., S. Nickell and R. Jackman, (1991). Unemployment: Macroeconomic Performance and the Labour Market, Oxford University Press, Oxford.

Le, A.T. and P.W. Miller, (1999). "A Risk Index Approach to Unemployment: An Application Using the Survey of Employment and Unemployment Patterns", Australian Bureau of Statistics Occasional Paper, Cat no. 6293.0.00.001.
Lewis, P. and M. Kirby, (1988). "A New Approach to Modelling the Effects of Income Policies", Economics Letters, Vol. 28, No. 1, pp.81-85.

Lewis, P. and A. Seltzer, (1996) "Labour Demand", in K. Norris and M. Wooden (Eds.), The Changing Australian Labour Market, Australian Government Publishing Service, Canberra, pp. 39-52.

Martin, J.P., (1998). "What Works Among Active Labour Market Policies: Evidence from OECD Countries' Experience", in G. Debelle and J. Borland (Eds.), Unemployment and the Australian Labour Market, Reserve Bank of Australia, Sydney, pp.276-302.

McDonald, J.T. and C. Worswick, (1999). "Immigrant Assimilation in a Regulated Labour Market: Unemployment of Immigrant Men in Australia", mimeo, Department of Economics, University of Tasmania.

Miller, P.W., (1986). "Unemployment Patterns in the Youth Labour Market", Australian Economic Papers, Vol. 25, No. 47, pp.222-235.

Miller, P.W., (1990). "Aboriginal Youth Unemployment", in J.C. Altman (Ed.), Aboriginal Employment Equity by the Year 2000, Centre for Aboriginal Economic Policy Research, Australian National University, Canberra, pp. 79-90.

Miller, P.W., (1998). "Youth Unemployment: Does the Family Matter", Joumal of Industrial Relations, Vol. 40, No. 2, pp.247-276.

Miller, P.W. and L.M. Neo, (1997). "Immigrant Unemployment: The Australian Experience", Intemational Migration, Vol. 35, No. 2, pp.155-183.

Miller, P.W. and P.A. Volker, (1985). "Unemployment Insurance Eligibility Rights: Evidence from a Comparison of Australia and Canada", Journal of Macroeconomics, Vol. 7, No. 2, pp.223-235.

Miller, P.W. and P.A. Volker, (1987). "The Youth Labour Market in Australia: A Survey of Issues and Evidence", Centre for Economic Policy Research, Discussion Paper No. 171, Australian National University.

Moore, D., (1997). "The Effects of the Social Welfare System on Unemployment", Australian Bulletin of Labour, Vol. 23, No. 4, pp.275-294.

Morony, R., (1990). "The Community Development Employment Projects (CDEP) scheme", in J.C. Altman (Ed.), Aboriginal Employment Equity by the Year 2000, Academy of the Social Sciences in Australia, Canberra, pp.101-106.

Morrell, S., R. Taylor and C. Kerr, (1998). "Unemployment and Young People's Health", Medical Joumal of Australia, Vol. 168, No. 5, pp.236-240.

Nakamura, A. and M. Nakamura, (1985). The Second Paycheck: A Socioeconomic Analysis of Earnings, Academic Press, Florida. 
Ooi, S.H. and N. Groenewold, (1992). "The Causes of Unemployment in Australia 19661997", Australian Economic Papers, Vol. 31, No. 58, pp.77-93.

Piggott, J. and B. Chapman, (1995). "Costing the Job Compact", Economic Record, Vol. 71 ,No. 215 , pp.313-328

Pissarides, C., (1991). "Real Wages and Unemployment in Australia", Economica, Vol. 58 , No. 229 , pp.35-55.

Richardson, C., (1998). "Unemployment or Tax Reform?", in G. Debelle and J. Borland (Eds.), Unemployment and the Australian Labour Market, Reserve Bank of Australia, Sydney, pp.342-356.

Ross, R.T., (1985). "Improved Labour Market Information: Beyond Unemployment Statistics", Australian Bulletin of Labour, Vol. 11, No. 4, pp.236-245.

Ross, R.T., (1990). "Employment Prospects for Aborigines in New South Wales", in J.C. Altman (Ed.), Aboriginal Employment Equity by the Year 2000, Centre for Aboriginal Economic Policy Research, Australian National University, Canberra, pp. 121-132.

Ross, R., (1992). "The Dynamics of Underutilisation of Youth Labour", in R.G. Gregory and T. Karmel (Eds.), Youth in the Eighties: Papers from the Australian Longitudinal Survey Research Project, Department of Employment, Educatio and Training, Canberra, pp.305-318.

Ross, R., (1993). "A Probit Analysis of Aboriginal Employment Prospects in New South Wales", Economic Record, Vol. 69, No. 206, pp.253-258.

Russell, B. and W. Tease, (1991). "Employment, Output and Real Wages", Economic Record, Vol. 67, No. 196, pp.34-45.

Seltzer, A., (1997). "An Evaluation of the International Evidence on the Employment Effects of Minimum Wage Legislation", Australian Economic Record, Vol. 30 No. 2, pp.208-214.

Sloan, J. and M. Wooden, (1987). "Labour Market Programs", in J. Freebaim, M. Porter and C. Walsh (Eds.), Spending and Taxing: Australian Reform Options", Allen and Unwin, Sydney, pp.146-165.

Stacey, G. and P. Downes, (1995). "Wage Determination and the Labour Market in the Treasury Macroeconomics (TRYM) Model", Paper Presented at the $24^{\text {th }}$ Conference of Economists, Adelaide.

Stromback, T., M. Dockery and W. Ying, (1998). "Transitions in the Labour Market: Evidence from the Survey of Employment and Unemployment Patterns", Centre for Labour Market Research, Discussion Paper 98.2.

Stromback, T., A.M. Dockery and W. Ying, (1999). "Labour Market Programs and Labour Force Status", Australian Bulletin of Labour, Vol. 25, No. 2, pp.159-178.
Taylor, J., (1993). The Relative Economic Status of Indigenous Australians, 1986-91, Centre for Aboriginal Economic Policy Research, Australian National University, Research Monograph No. 5.

The Treasury, (1999). Economic Round Up: 1999 Winter, The Treasury, Canberra.

Trivedi, P.K. and G.M. Baker, (1985). 'Equilibrium Unemployment in Australia: Concepts and Measurement", Economic Record, Vol. 61, No. 174, pp.629-643.

Trivedi, P.K. and C. Kapuscinski, (1985). "Determinants of Inflow into Unemployment and the Probality of Leaving Unemployment: A Disaggregated Analysis", in P.A. Volker (Ed.), The Structure and Duration of Unemployment in Australia: Proceedings of a Conference, Australian Govemment Publishing Service, Canberra, pp.151-185.

Tyers, R. and Y. Yang, (1997). "Trade With Asia and Skill Upgrading: Effects on Labor Markets in the Older Industrial Countries", Weltwirtschaftliches Archiv, Vol. 133, No. 3, pp.383-417.

Valentine, T., (1993). "The Sources of Unemployment: A Simple Econometric Model", Economic Papers, Vol. 12, No. 4, pp.1-20.

Weiss, A., (1995). "Human Capital vs Signalling Explanations of Wages", Journal of Economic Perspectives, Vol. 9, No. 4, pp.133-145.

Welch, F., (1995). "Review Symposium: Myth and Measurement: The New Economics of the Minimum Wage: Comment", Industrial and Labour Relations Review, Vol. 84 , No. 4, pp.842-849.

Whitlock, B., (1994). "Does the Social Security Income Support System Remove the Incentive to Work?", Department of Social Security Policy Discussion Paper No. 4, Australian Government Publishing Service, Canberra.

Wood, A., (1997). "Discussion of John Freebairn's 'Unemployment'", in Industry Commission, Changing Labour Markets: Prospects for Productivity Growth, Industry Commission, Sydney, pp.151-153.

Wooden, M., (1991). "The Experience of Refugees in the Australian Labour Market", Intemational Migration Review, Vol. 25, No. 3, pp.514-535.

Wooden, M., (1993). "Underemployment in Australia", Labour Economics and Productivity, Vol. 5, No.2, pp.95-110.

Wooden. M., (1996). "Hidden Unemployment and Underemployment: Their Nature and Possible Impact on Future Labour Force Participation and Unemployment", National Institute of Labour Studies, The Flinders University of South Australia, Working Paper No. 140. 


$$
3
$$

Clements, K.W. Barrett, $\mathrm{J}$.

Daryal, M.

99-18 Islam, $N$

Crompton, P.

Qiang, Y. data

The economics of marijuana consumption China region analysis for Malaysia, 1966-96 models using Australian data approach

Future trends in Japanese steel consumption

The numerical implementation of WAM

Qiang, Y.
Report of the $1999 \mathrm{PhD}$ conference in economics and business Wage effects of drinking and smoking: an analysis using Australian twins

Prices, legislation and marijuana consumption

Minerals and regional employment in Western Australia

Western Australian agriculture: structure, trends and farming systems

A history of bimetallism: Greece, Rome, Middle Ages, Modem Times

The Trade Practices Act after 25 years: mergers and the role of the ACC

Income disparity and convergence in China's regional economies

Regional integration, productivity and growth: a study of the Southem

Export performance and economic growth: co-integration and causality

Violation of the IID-Normal assumption: Effects on tests of assett-pricing

Estimating the WA agricultural production system: A profit function

How different is mining from mineral processing?

The economy-wide effects of expansion of the minerais sector

An economy-wide model of Westem Australia: the theoretical structure

The nature of the Western Australian economy Fraser, $P$.

Forecasting beta: how well does the 'five year rule of thumb' do?

Lee, Y.L.

Magnani, L.

Le, A.T.

Greig, $R$.

Gruen, D. Kortian, T.

Clements, K.W

Chen, D.

\section{dique, M.A.B.} Selvanathan, E.A.

Groenewold, N. Hagger, A.

Macfarlane, I.J.

Ahanmad, $\mathrm{H}$.

Greig, R.

\section{Groenewold, N.}

Fraser, $\mathrm{P}$.

Yuen, W.C.

Wu, Y.

Le, A.T.

Clements, K.W. Qiang, Y.

Clements, K.W. Qiang, Y.

98-13

Ghosh, R.N. Siddique, M.A.B.

Ahammad, H.
Optimal schooling investments and earnings: an analysis using Australian twin data

Market volatility, adjustment of labor and earnings

Self employment and earnings among immigrants in Australia

The importance of the University of Western Australia to the state of Western Australia: a preliminary assessment

Why does the Australian dollar move so closely with the terms of trade?

Simulating Demand Systems

Export performance and economic development in Thailand

The Australian natural rate of unemployment: some estimates from a structural VAR

Shann Memorial Lecture:

Australian monetary policy in the last quarter of the twentieth century

Looking

Tests of asset-pricing models: how important is the IID-normal assumptions?

Food Consumption in rich countries

Redundancy and firm characteristics in Chinese state-owned enterprises

The determinants of immigrant self-employment in Australia

A new input-output table for western Australia - Part 2

A new input-output table for western Australia - Part 1
The labour market in the Maldives: the case for institutional reforms
The economics of the WA minerals sector : an overview of ERC research 

econometrics

The Westem Australian gold study

Part II

The Western Australian gold study Part I

The performance of foreign direct investment in China: a preliminary analysis

\section{Forecasting steel demand in South-East Asia}

\section{World metal prices: a database}

98-02 Selvanathan, S.

Ar econometric study of gold production and prices

Report of the $1997 \mathrm{PhD}$ Conference in economics \& business

Clements, $K$ Madsen, P. Clements, $\mathrm{K}$.

Greig, $R$.

Metal markets and East Asia: emerging trends, issues and policies Part III

Metal markets and East Asia: emerging trends, issues and policies Part II

Metal markets and East Asia: emerging trends, issues and policies Part I

The world real interest rate: stochastic index number perspectives

An analysis of the implications for the gold mining industry of altemative tax policies: a regional disaggregated model for Australia :

$-4582000$

\section{(9) 1007 thin}

\section{1042000}

